\title{
CLARÍN CONTRA EL LUCERO DEL ALBA (MARQUÉS DE LA PEZUELA, CONDE DE CHESTE)
}

\author{
MARIO HERNÁNDEZ \\ Universidad Autónoma de Madrid
}

Si a los españoles de aquella época les hubieran preguntado quién era Clarín, la mayoría habría respondido: «Un escritor agudo y mordaz que en varios periódicos y revistas publicaba muy a menudo unos artículos breves, titulados "Paliques", en que se metía con el lucero del alba».

RAMÓN PÉREZ DE AYALA ${ }^{1}$

Don Juan de la Pezuela y Ceballos, marqués de la Pezuela y conde de Cheste, nació en Lima en 1809, hijo de quien llegaría ser penúltimo virrey del Perú2. Moría en Madrid en 1906, después de haber presidido durante 31 años la Real Academia Española de la Lengua. Militar y político isabelino, vio sucumbir ante sus ojos el

1 «Clarín y don Leopoldo Alas», Archivum, II, 1 (1952), pp. 5-21; 9.

2 De Joaquín de la Pezuela (1761-1830), virrey entre 1816 y 1821, puede consultarse su Memoria de gobierno, edición y prólogo de Vicente Rodríguez Casado y Guillermo Lohmann Villena, Sevilla, Escuela de Estudios Hispano-Americanos, 1947. Trazó una biografía positiva del hijo, sobre documentación de archivo familiar, Antonio de Urbina y Melgarejo, marqués de Rozalejo, en Cheste o todo un siglo (1809-1906). El isabelino tradicionalista, Madrid, Espasa-Calpe, 1935. 
antiguo régimen, asistió a su dura y larga agonía y luchó, con otros muchos, en un siglo complejo y difícil por preservar sus ideales conservadores. Gozó de la estima personal de Isabel II y del apoyo de sus correligionarios politicos y académicos, como Mariano Roca de Togores, primer marqués de Molins, quien le precedió en la dirección de la Real Academia y le prologó su traducción de La divina comedia. Olvidado hoy su nombre entre los entorchados y espadas del XIX, resurge en estas páginas al calor de uno de sus enemigos, Leopoldo García Alas, catedrático de las universidades de Zaragoza y Oviedo, periodista y crítico literario temido en su tiempo, además de autor de La Regenta y de otro valioso puñado de narraciones.

Discípulo de Lista y Hermosilla, y condiscípulo de Espronceda y Ventura de la $V e g a$, el conde de Cheste fue un modesto poeta, pero fue sobre todo conocido por sus traducciones de grandes poetas: además de la de Dante, las de Tasso (1855), Camoens (1872) y Ariosto (1883), primera que había iniciado y que remató en la vejeż. Como otros muchos personajes públicos de su época, había ingresado en la Real Academia de la Lengua, lo que tuvo lugar en 1845, alcanzando su presidencia en 1875. Gracias a una perezosa conveniencia, su desmañada versión de La divina comedia se ha seguido reeditando hasta hoy mismo, sin duda por la dificultad o encarecimiento para un editor de encargar nuevas versiones a nuevos traductores. La suya apareció en 1879, en tres sólidos volúmenes, como La comedia de Dante Alighieri, traducida al castellano en igual clase y número de versos ${ }^{4}$.

Clarín le ridiculiza de modo sangrante, burlándose de su retórica, en uno de sus Folletos literarios, en el brillante Apolo en Pafos (interview) ${ }^{5}$, pero no dejó de aludir a él en múltiples ocasiones y desde fechas tempranas, a veces con patente dureza. Recorro aquí algunas de esas menciones, desde luego que sin ánimo exhaustivo, y lo hago desde las preocupaciones técnicas de un gran escritor en un medio intelectual y político concreto. El contexto apela de modo inevitable a la Real Academia de la Lengua, cuya labor y significado fue una de las preocupaciones de Clarín. No pretendo examinar los debates léxicos o lingüísticos del momento ${ }^{6}$, sino tratar de penetrar en las posiciones

\footnotetext{
${ }^{3}$ La Jerusalén libertada de Torcuato Tasso, puesta en verso castellano y dedicada a la reina doña Isabel II por el teniente general marqués de la Pezuela, Madrid, Aguado, 1855, 2 vols.; Los Lusiadas. Poema épico traducido en verso castellano, Madrid, A. Pérez Dubrull, 1872; Orlando furioso. Poema heroico de Lodovico Ariosto traducido en verso castellano, Madrid, A. Pérez Dubrull, 1883, 4 vols. Las tres primeras octavas del canto II son traducción juvenil de Espronceda, huella amistosa que Pezuela quiso preservar, según él mismo indica (I, p. 6). Datos biográficos esenciales, en Juan Valera, «Notas biográficas y críticas», Obras Completas, II. Crítica literaria, Madrid, Aguilar, 1961, p. 1295.

4 Pról. marqués de Molins, Madrid, Tip. de D. Antonio Pérez Dubrull, 1879. A lo largo del siglo XX ha circulado impresa por diversas editoriales, principalmente Aguilar. Última edición que registra el catálogo de la BNE: Madrid, Edaf, 2003.

${ }^{5}$ Madrid, Librería de Fernando Fe, 1887, pp. 37-38.

6 Se ha ocupado de la historia del diccionario académico y de las polémicas relativas a la 12. ${ }^{\mathrm{a}}$ edición (1884), con activa participación, entre otros, de Clarín, Gloria Clavería Nadal en «La Real Academia Española a finales del siglo XIX: el Diccionario de la Lengua Castellana de 1899 (13. ${ }^{\text {}}$
} 
que en ese terreno tenía, como escritor, Leopoldo Alas, periodista fecundo, agudísimo y torrencial. Y lo hago desde un lugar preciso, que ha de servirme de referencia central: el artículo, y poema primero que engloba, "Consulta crítica», publicado en 1884 en el semanario Madrid Cómico y probablemente escrito en un descanso de su redacción de La Regenta. Para ello analizo en primer lugar el contexto periodístico en el que el poema aparece, para centrarme después, tras la edición y anotación de ese poema, en una de las vertientes de la parodia: la lengua literaria del de Cheste, o la visión que de ella tenía Clarín. El contexto literario es de más amplio radio, pues atañe, por ejemplo, a las discusiones de época sobre el verso libre, con piezas como la modélica "Epístola a Horacio» de Menéndez Pelayo, que Clarín y Darío alabaron y Borges guardaba en su memoria. Quede para otra ocasión ese nuevo y ondeante fleco de endecasílabos libres (sobre fondo de hexámetros).

Clarín edita su artículo "Consulta crítica», con el poema (o poemas) que engloba, en Madrid Cómico (1-VI-1884), modesta y célebre revista semanal que dirigía Sinesio Delgado y donde colaboraban las plumas festivas y satíricas del momento, como Eduardo del Palacio, Luis Taboada, Vital Aza, Manuel Matoses o el mismo Leopoldo Alas7. El poema, a pesar de su empaque y de su raro lenguaje, no desentonaba del todo en aquellas páginas dominicales, que se iniciaban con una caricatura de un personaje público - político, actor, escritor, cantante...- y podían terminar en su página final con el dibujo caricaturesco de un «tipo» de la sociedad del momento: una modistilla, un sereno (indefectiblemente gallego), un golfante, un pintor en su estudio, un inglés que husmea cachivaches antiguos, etc.

Firmaba las caricaturas iniciales (como los «tipos») Francisco Ramón Cilla, a cuya hábil pluma se debe el conocido retrato de un Clarín de cuerpo desmedrado y gran cabeza realista, según esquema creado por este «sainetero

edición)», BRAE, LXXXIII, CCLXXXIII (2003), pp. 255-336; 255-265. Una visión primera de conjunto, en Francisco Abad Nebot, «Ideas sobre la lengua y los usos lingüísticos de Clarín», «Clarín» y «La Regenta» en su tiempo. Actas del Simposio Internacional, Oviedo, Universidad, Ayuntamiento, Principado, 1987, pp. 985-995.

7 Narciso Alonso Cortés, «Clarín y el Madrid Cómico», Archivum, II, 1 (1952), pp. 43-61; JeanFrançois Botrel, La diffusion du «Madrid Cómico». 1886-1897 (Presse et public), Rennes, Université de Rennes 2 Haute Bretagne, 1982; «71 cartas de Leopoldo Alas, Clarín, a Sinesio Delgado, director de Madrid Cómico», Boletín del Real Instituto de Estudios Asturianos, 149 (1997), pp. 7-53; «Clarín y el Madrid Cómico. Historia de una colaboración», en «Clarín» y «La Regenta» en su tiempo..., op. cit., 1987, pp. 3-24. Una descripción de Madrid Cómico y sus distintas etapas, desde 1880, en María Pilar Celma Valero, Literatura y periodismo en las revistas del Fin de Siglo (1888-1907). Estudio e indices, Madrid, Júcar, 1991, pp. 21-28. La $1^{\text {a }}$ ed. de "Consulta crítica» ya fue señalada por Antonio Vilanova (ed. y pról.), Nueva campaña, Barcelona, Lumen, 1990, índice final. 
del lápiz», como le llamó Fernández Almagro8: mientras el retratado extiende el brazo derecho y el dedo índice como si señalara a «las tinieblas exteriores», con el otro sostiene una gran pluma cuya punta ensarta y atraviesa a un pequeño monigote que le ofrece una cuartilla; se lee en ella con relativa claridad una sola palabra: «POESÍA»; el crítico, con el ceño fruncido y el gesto severo, está haciendo lo que solía: mandar a un poeta al averno. Por si hubiera dudas, al pie del recuadro que enmarca el dibujo una quintilla anónima, probablemente del mismo Cilla9, identificaba al retratado:

\section{Es un crítico eminente} que zurra divinamente a los escritores malos, $\mathrm{y}$ vive pegando palos a todo bicho viviente ${ }^{10}$.

No es una quintilla de Lope, pero cumple su cometido, en este caso de presentación de un crítico que había sido contratado expresamente por su severidad con los poetas chirles y por su mismo ingenio para «el palo», al margen de la altura del sometido a crítica. Clarín se incorpora a esta segunda etapa de Madrid Cómico, que se había iniciado, bajo la dirección de Sinesio Delgado, el 5 de febrero de 1883, y que duraría hasta 1898. modo:

El periódico se anunciaba —en su propia página de anuncios— de este

\footnotetext{
8 En «Sinesio Delgado en su tiempo», prólogo a S. D., Mi teatro, Madrid, Sociedad General de Autores de España, 1960, pp. 7-15.

${ }^{9}$ La firma correspondería, pues, a dibujo y versos. No le faltaba habilidad versificatoria a Cilla, como demuestra en las quintillas burlescas de «jGracias! (a Eustaquio Cabezón, con motivo u ocasión de un regalito que consta en el texto)», Madrid Cómico, 23-III-1884, p. 7. A veces intervendría el director, según ha escrito Alberto Delgado: «Sinesio, en el Madrid Cómico, ajustaba grabados, ponía pies a los dibujos, corregía planas, estaba al tanto de la administración, llevaba su sección "Chismes y cuentos", hacía crítica teatral, con el seudónimo de Luis Miranda Borge, hasta que estrenó su primer sainete, y despachaba la "Correspondencia particular", a la que acudían con sus versos muchos aspirantes a famosos». «Pequeña biografía de Sinesio Delgado», en $M i$ teatro, op. cit., p. 18. Tardíamente, Clarín recordaba a Delgado, diciendo de él que, además de empresario de Madrid Cómico, «era obrero, capataz. Nos dirigía, escribía versos, cabos sueltos, inventaba secciones, tenía un plan, un criterio...». Heraldo de Madrid, 3690 (18-XII-1900), en Paliques, ed. Carlos Dorado, Madrid, Ayuntamiento, 2003, p. 727.

10 Caricatura y versos, en Madrid Cómico, 2 (4-III-1883), p. 1. Es plausible la autoría de la copla por dos razones: firma, que englobaría dibujo y pie, y aludida habilidad de Cilla para el verso. La reproducción reducida del dibujo impide la lectura de la voz «POESÍA», como sucede en OC, VII. Artículos (1882-1890), ed. J.-F. Botrel e Y. Lissorgues, Oviedo, Nobel, 2004, p. 304.
} 
Clarín contra el lucero del alba (Marqués de la Pezuela, Conde de Cheste)

\title{
MADRID CÓMICO
}

\author{
PERIÓDICO SEMANAL, LITERARIO, FESTIVO, ILUSTRADO
}

\section{Se publica los domingos y contiene}

\author{
ARTÍCULOS Y POESÍAS DE NUESTROS PRINCIPALES LITERATOS \\ Y VIÑETAS Y CARICATURAS DE LOS MEJORES DIBUJANTES
}

Periódico o revista semanal, estaba al servicio de una sociedad que se entretenía con el humilde ingenio de poetas hábiles, fáciles de rima y humor, y de prosistas entregados al chiste, al chascarrillo o al esbozo de costumbres contemporáneas. La amabilidad de aquellas letras dominicales entraba también por los ojos gracias al trazo caricaturesco o costumbrista de los dibujantes, entre ellos el entonces famoso Cilla, así descrito con los correspondientes versos al pie de su caricatura, ahora firmada por su colega Mecachis:

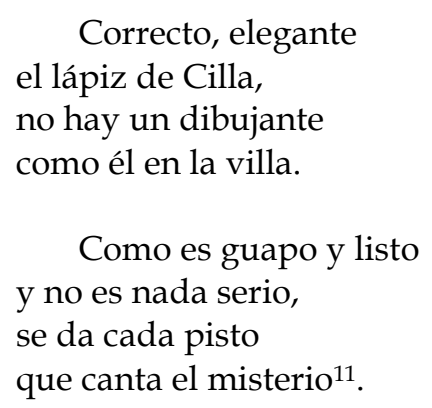

Con este tono y solfas, podría decirse que el título de Madrid Cómico y el ánimo de sus colaboradores no engañaban, pues aquellas páginas dominicales tenían una intención fundamentalmente festiva, sin ánimo de herir o satirizar a personas e instituciones. Descontada la excepción de Clarín, que sí podía hacer sangre con su pluma, prosa y poesía adoptaban en la revista un aire cómico de puro entretenimiento. En la misma página de la «Consulta» clariniana —columna con columna - aparece un romance de Vital Aza — «in de curso. Monólogo de un estudiante» $\longleftarrow$, donde se glosan con amable humor los apuros del mal estudiante en el trance del final de curso. También se ofrecen allí unos

11 F. R. Cilla (1859-1937), Madrid Cómico, III, 31 (23-IX-1883). La locución «que canta el misterio» ha de entenderse como 'muy grande', con intención ponderativa; hoy se diría «que tiembla el misterio», tal como recoge el Diccionario del español actual, de Manuel Seco, Olimpia Andrés y Gabino Ramos (Madrid, Santillana, 1999), en adelante DEA. 
chistosos «Epigramas», que rinden pleitesía a los de Moratín (padre e hijo) o Cadalso. Estos son de Juan Martínez Villergas, a quien don Juan Valera, ya doblado el cabo del siglo, elogiaría por «su agudeza, su gracia, su rara facilidad de estilo y su fecunda y viva imaginación»12. Copio el primero y mejor, en quintillas:

\author{
Guillén cenó con Pascual. \\ Una ensaladita escasa \\ fue el comienzo, y -iVoto a tal! \\ -exclamó aquel-. En mi casa \\ ese es el plato final. \\ Pero más la admiración \\ creció del pobre Guillén \\ al ver el aire simplón \\ con que su buen anfitrión \\ contestó: - Y aquí también.
}

A pesar de su tono más ácido, de su buen pulso coloquial y de su indudable agudeza, la prosa de la «Consulta crítica» de Clarín no desentonaba en ese contexto. He aquí el arranque de su artículo:

Aunque los críticos sean, o seamos, ¡qué diablo!, viboreznos ingratos para España, como dijo el P. Isla hablando de otros López, no dejamos de tener quien nos consulte, con el objeto, dicen ellos, de que «juzguemos imparcialmente sus obras».

Yo, aunque indigno, he perdido ya más dramas que pelos tengo en la cabeza a otros tantos poetas irrepresentables, que «querían saber mi opinión sin ambages ni rodeos».

Mi opinión solía ser esa: perderles el drama ${ }^{13}$.

No obstante, si pasamos después al poema de «Consulta crítica», pronto nos damos cuenta de que tanto el léxico, como su extensión y el tratamiento, lo singularizan como pieza aislable y de importancia. No se escribe una sólida composición de 67 endecasílabos libres para perderla (como aquellos dramas) en las efímeras páginas de un semanario humorístico, ni siquiera como ilustración de un artículo de sátira literaria. Es claro que el poema no quedó perdido, pues el ya autor de La Regenta rescató su "Consulta crítica» para un

\footnotetext{
12 Florilegio de poesías castellanas del siglo XIX, con introducción y notas biográficas y críticas, Madrid, Librería Fernando Fe, 1902-1903, 5 vols; I, p. 192.

${ }^{13}$ En la versión del periódico se lee «...que de pelos tengo...», con evidente errata.
} 
nuevo volumen, recopilatorio y selectivo: Nueva campaña (1885-1886)14. A pesar de ello, no deja de suscitar preguntas el simple hecho de que Clarín rebajara su importancia al incluirlo como ilustración festiva de su propuesta: el trato que había de darse a los malos poetas dramáticos, o a los metidos porque sí a dramaturgos. Nada de edición noble, con posible cita de Horacio o de Juvenal al frente, sobre página de albura o ahuesado perfectos, sino líneas apretadas de doble columna entre versos ligeros y apenas recordables (es decir, escondiéndolo en medio de la plaza, a la vista de todos). Jugando de nuevo a las contradicciones, hoy el poema clariniano puede y debe ser leído como pieza exenta y como muestra del magisterio lingüístico y satírico del poeta que lo escribió. Para ello es conveniente recorrer los datos circunstanciales que lo acompañan e históricamente lo complementan.

Antes, unas palabras sobre el texto que edito. Lo he fijado y anotado a partir de su edición definitiva en Nueva campaña, manteniendo un párrafo previo que ayuda al lector a situarse. Interpreto que tanto el artículo como el poema tienen el mismo título, máxime teniendo en cuenta que la segunda parte del mismo artículo, tras una apostilla de cierre, reproduce miméticamente una situación semejante de consulta crítica, ahora por parte de un poeta fingido, Rufino Cachivaches, que quiere introducirse en la corte. El articulista y crítico se burla entonces, con suma de ejemplos, de la ropavejería retórica del vate, que medievaliza como un Duque de Rivas de deshecho:

Y la pluma, que en los dedos
a impulsos del alma tiembla,
el crujiente pergamino
salpica de tinta negra.
A la luz de tres bujías,
que un candelabro sustenta,
y agita el viento que sopla
de una ventana entreabierta,
se mira el bello recinto
de una ancha cámara extensa,
los muros con colgaduras
y con tapices las puertas ${ }^{15}$.

La versión de la primera y más seria parodia (que eso es en parte la «consulta» en endecasílabos libres) fue trasladada al libro con cuidadosa

\footnotetext{
14 Madrid, Librería de Fernando Fe, 1887, pp. 319-325; el poema, en pp. 319-321.

15 Elimino los comentarios intercalados entre los octosílabos, para reconstruir una tirada seguida. Hemos de suponer que el romance es una parodia del propio crítico, de acuerdo con una costumbre largamente ensayada en la prensa por Clarín (u ocasionalmente por Sinesio Delgado).
} 
atención, sobre todo del autor, que hubo de salvar las tropelías que los sufridos cajistas habían cometido en Madrid Cómico con sus indescifrables versos y ortografía $^{16}$. Si ya su letra tenía justa fama de oscura, la densa secuencia de neologismos, latinismos y helenismos del largo poema hubo de poner a prueba la pericia de la imprenta que componía el semanario ${ }^{17}$. El autor enviaba desde Oviedo los originales, pero no estaba a pie de obra para las correcciones, y la prensa no admitiría la ida y vuelta de pruebas que sí era posible con los libros. No es extraño que en ciertos casos se viera obligado a comentar en sus escritos los problemas que le habían causado las erratas. Tres años después ironizaba con humor sobre lo que podía ocurrir, y de hecho ocurría (cuando la enmienda aún era posible): «Más de una vez, al corregir las pruebas de mis libros, me he encontrado con escolios de estos al margen: “ ¡Mal rayo te parta! ¡Vaya una letra que usa V., compadre! ¡Mejor le fuera aprender a escribir que meterse a criticar! ¡Escribir de ese modo es robarle el sudor de su frente al pobre trabajador de la imprenta!", etc., etc.»18. Aunque es obvio que cargaba las tintas, también denotaba el claro conocimiento de su culpa.

En este caso el trabajo de los cajistas fue aproximadamente meritorio, pero no se pudieron evitar algunos dislates: aróspice («arúspice»), desceñendo («desciñendo»), clundicante («claudicante»), vete («vate»), ceráleo («cerúleo»), ganua («janua»). Mientras la segunda variante parece una errata común, las demás sugieren la lectura incorrecta de un manuscrito difícil por alguien que lo ignora todo sobre el vocablo que lee. Resalta, no obstante, un raro término, difícilmente inventado por el cajista, que hubo de esforzar ojos y tipografía: «higroaurícroma» (luego se convertiría en «auricroma»). ¿Se le fue la mano (y la fantasía) a Clarín? En Madrid Cómico se leía el descabalado endecasílabo de este modo: «Mas ¡ay! de aquella fámula higroaurícroma...»19. El autor corrigió luego el exceso — léxico e imaginativo—, y su «blonda fámula» fue dos veces rubia o

\footnotetext{
16 Breves noticias sobre la composición del libro en Josette Blanquat y Jean-François Botrel, ed. y notas, Clarín y sus editores. 65 cartas inéditas de Leopoldo Alas, Fernando Fe y Manuel Fernández Lasanta, Rennes, Université de Haute-Bretagne, 1981, pp. 31-33. Retoma y contextualiza estos datos Antonio Vilanova en el prólogo a su edición de Nueva campaña, op. cit. Como he advertido, en el índice final el nuevo editor señala la procedencia de los artículos, entre ellos el de «Consulta crítica».

17 Galdós hablaba de la «escritura caldea» de su amigo. En Juan Antonio Cabezas, «Clarín», el provinciano universal, Madrid, Espasa-Calpe, 1962, p. 126, con otro testimonio idéntico de E. Pardo Bazán. Soledad Ortega habla de «lo endiablado de la escritura de Alas» (Cartas a Galdós, Madrid, Revista de Occidente, 1964, p. 17). J. Blanquat y J.-F. Botrel han lamentado también que en algunos casos «a pesar de muchos esfuerzos, propios y ajenos, no hemos podido descifrar la letra de Clarín» (ed. cit., p. 4). Confieso la misma experiencia con algunos autógrafos que guarda la BNE. 18 Palique de Madrid Cómico, 248 (19-XI-1887), ed. cit., pág. 244.

${ }^{19}$ En el microfilm que he consultado en la Hemeroteca Municipal de Madrid la tilde es dudosa; en el original que poseo no admite duda.
} 
áurea sin necesidad de que interviniera para ello nada relativo a líquido o humedad alguna (por v́үpós, en el griego de «higrómetro», por ejemplo).

Otras observaciones menores: frente a Nueva campaña restablezco un punto después de «de furia alalo»y antes de «Ampos de Holanda» (perífrasis metafórica, y ampulosa, de 'sábanas'); en el libro (que no en Madrid Cómico), se perdió el signo, pero no la mayúscula de «Ampos»; añado también el de admiración tras «hóspite», que falta en las dos ediciones; por último, he escalonado los segmentos de un verso con diálogo y modernizado la ortografía, retocando mínimamente la puntuación, que el autor usaba por lo común con atinada precisión ${ }^{20}$.

\section{CONSULTA CRÍTICA}

[...] En una ocasión, y siento que el hecho no sea todo lo idealista que yo quisiera..., pero, en fin, allá ustedes; en una ocasión dormía yo el sueño de los perezosos — cinco horas después de terminado el de los justos-, cuando..., pero esto debe referirse en verso libre y pudibundo ${ }^{21}$, y en el lemosín de Cheste:

Súbito hiere el tímpano sonoro
metal vibrante en címbalo de argento ${ }^{22}$
de menésico fáber ${ }^{23}$; blonda fámula ${ }^{24}$,
arúspice doméstico ${ }^{25}$, a mí llega,

${ }^{20}$ No atiendo a la edición del poema en OC, IV. Crítica (primera parte), ed. Laureano Bonet, con la colaboración de J. Estruch y F. Navarro, Oviedo, Nobel, 2003, pp. 870-871. Los editores corrigen «alalo», creando otro posible y duro endecasílabo, que no es de Clarín: «venciéndome pensé, de furia álalo»; desplazan también el acento, destruyendo otro verso, en «ananke»: «Al lamentable del ananké griego». Clarín acentuó perfectamente, y no hay que enmendarle la plana, ni cambiarle el sáfico. Por lo demás estos editores mantienen las carencias de puntuación que he señalado. Con mejor criterio, la Biblioteca Virtual Cervantes reproduce fielmente el poema tal como apareció en Nueva campaña..., al tiempo que da completo el libro.

21 verso libre es sinónimo en la época de 'endecasílabos blancos'. Clarín, además, ironiza: «libre y pudibundo», o 'soltero y virgen', sin coyunda de ningún tipo, sea por consonancia o asonancia.

22 címbalo de argento: 'campanilla de plata'. En su Aguja de navegar cultos y en la célebre «Receta para hacer Soledades en un día» Quevedo incluye «argento» entre las voces de la jerigonza culterana: «...cede, impide, cisuras, petulante, / palestra, liba, meta, argento, alterna...» (J. M. Blecua, ed., Obra poética, Madrid, Castalia, 1971, III, 825).

23 menésico fáber: 'artesano egipcio'. La campanilla argentina evoca a Menes, faraón legendario que encabezó la primera dinastía; unificó Egipto y fundó artes y escritura. Ya lo menciona Heródoto (II, 99). Vid. Historia, I y II, intr. F. R. Adrados, trad. y notas Carlos Schrader, Madrid, Gredos, 1992, pp. 385-386. «Menésico» atrae luego a «papiros» ('hojas', 'papel').

${ }^{24} \mathrm{La}$ 'rubia sirvienta' («blonda fámula» que luego será «auricroma») es probable reflejo de Petra, doncella de Ana Ozores en La Regenta, presentada en la novela como «rubia azafranada» (vid. infra, V). 
nuncio de visitante no serondo ${ }^{26}$, y en papiros herméticos ${ }^{27}$ mancipio dimisorias 28 lacónicas que ostentan el nomen, el prenomen y el cognomen ${ }^{29}$ de un comes, que me otorga ósculo en cifra sobre el cutis sutil del metacarpo ${ }^{30}$. Atraviesa cubículos dinteles el proxena ${ }^{31}$, exitando ${ }^{32}$ del vestíbulo;

25 Burlescamente la criada se convierte en «arúspice», es decir, 'sacerdote que en la antigua Roma examinaba las entrañas de las víctimas para hacer presagios' (DRAE). Ella es la intérprete doméstica, en este caso frente a un visitante 'no tardío o de tarde' («no serondo»), que llega a una hora tempranamente intempestiva. En La Regenta aparece un pillo, Bismarck, con aficiones de campanero, que en la torre de la catedral «manejaba el badajo de la Wamba con una seriedad de arúspice de buena fe» (ed. Juan Oleza, Madrid, Cátedra, 2001, 2 vols.; I, pp. 141-142).

26 serondo, 'aplicado a los frutos tardíos', es admitido por el DRAE en 1852. Corominas y Pascual recogen el ast. «serondu», 'otoñal, tardío' (DCECH), que acaso impulsó el uso de Clarín, anómalo, sino es por burla, en este contexto.

27 papiros herméticos pueden ser 'pliegos cerrados de una carta', pero el hermetismo puede implicar también una ironía sobre la capacidad expresiva del emisor, quien en todo caso se expresa lacónicamente (v. 7).

28 dimisorias: «las letras apostólicas, dichas así cuando un juez inferior envía la causa o proceso al juez superior, para quien se ha apelado, [...] o las letras con las cuales un prelado envía algún súbdito suyo a otro prelado para que le ordene...» (Covarr., ed. I. Arellano y R. Zafra, Madrid, Iberoamericana, 2006, s. v.). Recordaba Servando Teresa de Mier: «...pasé a Cádiz en 1811 con las correspondientes dimisorias del vicario general de Cataluña» (Memorias. Un fraile mexicano desterrado en Europa, ed. M. Ortuño Martínez, Madrid, Trama, 2006, p. 192).

29 Un ciudadano romano usaba praenomen, nomen gentilicium, que designaba a la gens a la que pertenecía, y un cognomen o cognomina ('apodos, sobrenombres') hereditarios. Vid. V.-J. Herrero Llorente, Diccionario de expresiones y frases latinas, Madrid, Gredos, 1995. El mismo personaje será luego aludido como «el crítico don Tal» (v. 27). M. Menéndez y Pelayo ofrece un verso equivalente en el uso de otra sabida serie de latinismos: «y addenda, y expurganda, y corrigenda». «Epístola a Horacio», en Odas, epístolas y tragedias, Madrid, A. Pérez Dubrull, 1883, p. 17.

30 Traslaticia e irónicamente las «dimisorias» se han convertido en la carta de recomendación de un colega de oficio (bajo el latinismo comes), que saluda al destinatario con un protocolario saludo «en cifra», del estilo de «s. s. q. b. s. m.» (seguro servidor que besa su mano). La poetisa malagueña Josefa Ugarte-Barrientos, luego condesa de Parcent, dedica al conde de Cheste sus Páginas en verso (Málaga, Imp. del Correo de Andalucía, 1882): «...me permito dedicarle este modesto libro como grato recuerdo de nuestras amenas veladas literarias. Que su lectura le sea agradable es la mayor satisfacción a que aspira su afectísima amiga Q. S. M. B.». Según Théophile Gautier, fórmula protocolaria de despedida era, para los hombres, «Beso a Ud. la mano» (Voyage en Espagne, Paris, Charpentier, 1865, p. 216).

31 «Próxenes» es título de huésped dado por un Estado griego a los extranjeros en determinadas circunstancias. (Enciclopedia universal ilustrada europeo-americana, Madrid, Espasa-Calpe, 1908-1930, s. v.)

32 Neologismo latinizante a partir de exire 'salir'; luego dirá: «buscó el éxito / de la cuadra» (vv. 6162), por 'la salida'. 
15

20 y enhiesto, macrocéfalo, con déficit en punto a pulcritud indumentaria; los cométicos bucles salomónicos claudicantes, cual flébiles folículas del vegetal patético a Desdémona ${ }^{33}$, a mí se apropincuó 34 ; yo era supino ${ }^{35}$. — ¿En qué puedo servirle? — dije en prosa-. Sus falangetes el luctuoso extremo córneo mostraron y, agarrado 36 , vide ${ }^{37}$ inédito producto de las máscaras ${ }^{38}$ en hirsuto papel —de barbas, vulgo-. -Este es el drama — pronunció aquel Tespis ${ }^{39}$ digno del carro, hablándome en plebeyo-, y el autor ego sum ${ }^{40}$; me recomienda el crítico don Tal, un buen amigo.

33 flébiles folículas... a Desdémona: los rizos de la cabellera (lat., coma) caen como llorosas hojillas de sauce, con perífrasis alusiva a la famosa canción de Desdémona en el acto cuarto, escena tercera, del Otelo shakesperiano. Es la «canción del sauce», de la que son estos versos: Sing all a green willow must be my garland. / Let nobody blame him; his scorn I approve.

34 De «apropincuarse», 'acercarse', cultismo latino de uso cómico o festivo. Hablan en Moreto un caballero ridículo y una criada que se finge condesa: «-Hablaros de espacio intento. —Pues apropincuad asiento» (El lindo don Diego, II, 1682-1683, ed. M. G. Profeti, Madrid, Taurus, 1983).

35 «Supino», 'tendido boca arriba', pero, alusivamente, 'ignorante, desconocedor' («ignorancia supina»). Comp.: «...soltando las sábanas que sus manos oprimían, resbaló en el lecho y quedó supina mientras el muro de almohadas se desmoronaba» (La Regenta, ed. cit., II, p. 182).

36 Con los miembros agarrotados, es decir, 'empavorecido'.

37 Forma arcaizante, por «vi», como en este terceto del Conde de Cheste: «Así vide en la sétima zaborra / a muchos transmutarse; y si he caído / aquí en error, la novedad lo borra». La comedia, I, Infierno, XXV, p. 276. Clarín lo usa por burla.

38 Alegres o tristes según respondan a la comedia o a la tragedia, lo que aquí no se especifica. Recuérdese la elegía «A las musas» de Leandro F. de Moratín: «...esta sonante lira, y flautas de oro, / y máscaras alegres, que algún día / me disteis, sacras Musas...». En Poesía completas (Poesías sueltas y otros poemas), ed. Jesús Pérez Magallón, Barcelona, Sirmio, 1995, p. 456; y Clarín, sobre Tamayo y Baus: «Aquel rostro es una máscara, pero no la de la comedia, porque no se ríe; ni la de Melpómene, porque no expresa el terror». Cito por Solos de Clarín, pról. José Echegaray, dibujos de Ángel Pons, Madrid, Enrique Rubiños, 1891, $4^{\mathrm{a}}$ ed. p. 35.

39 Tespis, poeta griego del siglo VI a. de C., a quien se atribuye la invención de la tragedia. Recorría el Ática con su carro para la representación de sus obras. En la primera edición del poema (Madrid Cómico, 1-VI-1884) Clarín añadió una nota con sapiencia (etimológica) de dómine: «Tespis y no Thespis, Temis y no Themis, teatro y no theatro, tesis y no thesis, tesoro y no thesoro». En Nueva campaña suprimió la nota.

40 En este «ego sum» resuenan citas bíblicas del tenor de «Ego sum qui sum» (Éxodo, 3, 14), «Ego sum lux mundi» (Juan, 8, 12), o «Ego sum via et veritas et vita» (ibídem, 14, 6). Clarín opone la grandeza de esas manifestaciones a la presentación que de sí hace el «digno del carro», pura y simple acémila. 


\author{
— ¿Sois árcade ${ }^{41}$ ? \\ -Señor, yo fui sereno \\ y ahora soy capataz en unas obras. \\ 30 \\ Suelo ser destajista, y a destajo \\ escribo dramas para hacerme rico, \\ y quisiera probar si este le sirve. \\ Con el rústico sermo cancelando \\ la inopinada cláusula, fue mudo. \\ 35
}

${ }^{41}$ De la Academia de los Árcades de Roma, fundada en el siglo XVII bajo la protección de la reina Cristina de Suecia. A ella pertenecieron, por ejemplo, los Moratín, el padre bajo el nombre arcádico o pastoril de Flumisbo Thermondonciaco; el hijo, como Inarco Celenio. Otro poeta del XVIII, Francisco Sánchez Barbero, fue Floralbo Corintio; ya en el XIX, el Conde de Cheste sería admitido como Olmisto Isaurense (Marqués de Rozalejo, op. cit., p. 44); un amigo y admirador de Menéndez Pelayo, el obispo mexicano Ignacio Montes de Oca, será Ipandro Acaico, como consta en sus libros. Siguiendo la tónica dieciochesca del poema, Clarín opone cómicamente petulancia cultista (del crítico que habla en Cheste) a prosaico realismo del metido a vate. Un clérigo de La Regenta, don Cayetano Ripamilán, «estimaba mucho a Meléndez Valdés y no poco a Inarco Celenio» (ed. cit., I, p. 187).

${ }^{42}$ Clarín recuerda, como en otros pasajes de su obra, el comienzo de la Ilíada (I, 39), cuando el sacerdote de Apolo, Crises, invoca en su defensa a Apolo Esminteo, que dispara sus fechas sobre los aqueos, y la peste se extiende por el campamento. Comp.: «Almorzaba tortilla de hierbas el dios Esminteo, el que lanza a lo lejos las saetas de su arco de plata» (Apolo en Pafos, op. cit., p. 5). Resuena también una composición de André Chénier, «L'Aveugle», dedicada a Homero: «Dieu dont l'arc est d'argent, dieu de Claros, écoute. / O Sminthée-Apollon, je périrai sans doute, / Si tu ne sers de guide à cet aveugle errant...»; largo poema que fue vertido por M. Menéndez Pelayo: «iOye mis ruegos tú, deidad de Claros, / Apolo Smínteo, el de la alada flecha / y arco de plata...». «El ciego. Idilio de Andrés Chenier», en Odas..., p. 277. Azorín describe la biblioteca personal de Clarín tras su muerte: «...entre dos novelas de Palacio Valdés asoma un ejemplar manoseado, leído y releído, de la Ilíada» («Oviedo. En la biblioteca de Clarín», en José María Martínez Cachero, ed., Leopoldo Alas, «Clarín», Madrid, Taurus, 1978, p. 62). La erudición estaría aquí al servicio de la burla.

43 'Mudo de furia'. El DRAE registra «álalo», 'mudo, privado del habla', helenismo que acepta en 1970; el DEA recoge también «alalo». Clarín ya usaba esta segunda forma en Apolo en Pafos..., op. cit., p. 42: «Por ese camino de citas retrospectivas va usted a llegar a la época del hombre alalo»; es decir, del 'mono o antropoide sin habla articulada' (Darwin mediante). En Ensayos y revistas, 18881892, Clarín hablará, al hilo de recuerdos universitarios, de «un curso que empezase por el pelasgo alalo y acabase con la famosa edad del hierro del latín» (Madrid, Manuel Fernández y Lasanta, 1892, p. 15). La palabra aparece, pues, en contextos teñidos, en más o en menos, de un carácter enfático-burlesco.

44 'Sacando el brazo de las sábanas', con sinécdoque de pars pro toto, habida cuenta que el «cúbito» es, según Autoridades, «la canilla mayor del brazo». 
Clarín contra el lucero del alba (Marqués de la Pezuela, Conde de Cheste)

40

manucapi del códice el follaje ${ }^{45}$.

Mas, jay!, de aquella fámula auricroma

por una culpa lata y mnemotécnica

— tal vez en el Leteo osculó el ánfora ${ }^{46}$,

yacía fuera del templete cúbico

de su jurisdicción, sobre la exenta ${ }^{47}$,

45

el inefable, cóncavo-convexo

receptáculo próvido al del gástero

producto liquiforme, de vesícula

indígena emigrante y rumoroso.

Flácido el pulso, dígitos enervo,

50

y el hirsuto volumen claudicante

en ondas de cristal bebió naufragios ${ }^{48}$.

Al lamentable del ananke ${ }^{49}$ griego

fenómeno fortuito, el vate en hórrida

fonética excelsión tocó el cerúleo

55

cóncavo sideral... Condonaciones

humildes postulé... Mas él, estoico:

—Gracias, me dijo, la lección comprendo;

ya sé lo que usté opina de mi drama

y mis versos ya sé para qué sirven».

45 'Cogí las hojas del original'. «Manucapi», neologismo latinizante a partir de un «*manucapere», que en recta derivación daría «manucepi». Clarín latiniza por burla y con excelente oído para su propia lengua. Su real capricho le permite antes un próximo (y distinto) «mancipio» ('recibo en mano'): «y en papiros herméticos mancipio...» (v. 6).

46 'Tal vez en el Leteo, o río de los muertos, bebió el agua del olvido'; pero cabe una interpretación más maliciosa: 'tal vez en el Leteo [donde se pierde la memoria] besó el jarro [de vino]'. Se suman en el poema dos formas de beso: «ósculo en cifra», «osculó el ánfora».

47 El «templete cúbico» sería una historiada 'mesilla' (con imitación de una forma arquitectónica muy del XIX); allí, sometido a la jurisdicción de la criada, se guardaría el 'no decible' («inefable») 'orinal' («cóncavo-convexo receptáculo...»), que yace sobre la «exenta» (seguramente, la 'alfombra o alfombrilla al pie de la cama').

48 Una construcción barroquizante, a lo Góngora, para la prosaica realidad: el drama se precipita sobre el líquido del orinal. No por azar Lope termina así un brillante soneto a don Luis: «Que como, si la envidia te desama, / en ondas de cristal, la lira orfea, / en círculos de sol irá tu fama» («Canta, cisne andaluz, que el verde coro...», ed. J. M. Blecua, Obras poéticas, I, Barcelona, Planeta, 1969, p. 888).

49 Helenismo común: 'necesidad' o 'fatalidad' (la que rige la tragedia). Aquí contrasta, para acentuar la mofa, con la puesta en culto de una frase hecha: «poner el grito en el cielo», o la «fonética excelsión» en el «cerúleo cóncavo sideral». Hablando de Don Álvaro o La fuerza del sino, Clarín usa el mismo término, pero acentuado a la francesa y como sustantivo femenino, según es usual: «...si sus fatalismos, imitados de las anankés extranjeras, no llamaban la atención del público...» (Rafael Calvo y el teatro español, Madrid, Librería de Fernando Fe, 1890, p. 51). 
Y no probando salvamento inútil

al náufrago poema, buscó el éxito

de la cuadra ${ }^{50}$ en tinieblas sumergida.

Tropezó con la janua y salió célere ${ }^{51}$.

Yo hundí en las plumas hemisferio antípoda ${ }^{52}$,

la extremidad abdominal distensa

hasta las horas tuve meridianas.

\section{III}

Clarín relata en su poema una escena de estirpe moratiniana, con ecos de La comedia nueva o El Café, pero con claves autobiográficas: visita a su casa, para requerir su opinión y apoyo, del consabido autor de un drama, capataz o destajista en una obra metido a dramaturgo. Quizá no sea impropio retomar la anécdota. He aquí lo narrado: mientras el crítico yace una mañana acostado, al parecer en reposo por molestias abdominales, sobreviene el sonido argentino de una campanilla; la criada, de cabellera rubia, le anuncia una temprana visita y le alarga una carta de recomendación en la que un colega de la crítica de teatros, con nombre y apellidos que se callan (pero que son aludidos con retintín), dice besar su mano; el visitante aparece ante él, que sigue tendido; el destajista metido a dramaturgo —desaliñado, negras las uñas, desordenado el pelo- le entrega una obra de teatro con la que quiere hacerse rico; pero, por fatal descuido, la criada, desmemoriada (y tal vez bebida), ha olvidado el orinal sobre la alfombra; distendido, el crítico deja laxos sus dedos y las hojas naufragan en el líquido infando; el escritor novel, que pone el grito en el cielo, rechaza excusas y huye veloz de la casa, tropezando con la puerta; el crítico, satisfecho, sigue descansando hasta el mediodía.

\footnotetext{
50 Transcribo para «cuadra» la primera acepción en los dos diccionarios que pudo tener a mano Clarín: «La sala o pieza espaciosa de una casa, habitación o edificio» (DRAE, 1869); o «(Del lat. quadra, cuadro, figura cuadrada.) Sala o pieza espaciosa» (DRAE, 1884). Cuadra puede significar también 'caballeriza' («principalmente entre los labradores», añadía Autoridades) y 'sala de un cuartel, hospital o prisión en que duermen muchos'. Clarín, latinizante, está haciendo uso de la primera acepción.

51 Clarín adopta la grafía latina de época: «janua», en lugar de «ianua» ('puerta'). No parece que estuviera en su deseo la castellanización con el sonido velar, que daría una bárbara sonoridad al endecasílabo. «Célere» es un latinismo en crudo: celeris, 'veloz' (como antes, «hóspite», de hospes, itis, o, entre otros más, «folículas»).

52 Sin mención de «hemisferio» alguno, Clarín evocará así a Ana Ozores, en un momento de crisis mientras yace enferma: «...la Regenta, incorporada en el lecho, entre murallas de almohadas, sola, oscuro ya el fondo de la alcoba...» (La Regenta, ed. cit., II, p. 182).
} 
Clarín muestra una vez más su maestría en el humor crítico y paródico. Hay en el poema una sostenida intención burlesca, que tiene varios frentes. Advierte el autor con malicia: «Siento que el hecho no sea todo lo idealista que yo quisiera». La mención del idealismo implica la presencia tácita de su contrario: el «innombrable» naturalismo, mirado con asqueada reticencia incluso por el culto y cosmopolita Valera en su prólogo a las entonces recientes Odas, epístolas y tragedias de Marcelino Menéndez y Pelayo ${ }^{53}$. El «naturalismo» del poema estaría, por ejemplo, en el hecho de que Clarín no rehúye (aunque los recubra de ironía) los datos fisiológicos realistas, como el «acceso» de una «hepática vorágine» que sufre, como crítico y poeta, mientras soporta la visita del incómodo «hóspite»; lo mismo cabría decir del «infando receptáculo» y del «naufragio» de las hojas en él, así como del relajado momento final, cuando, ya en solitario, el autor puede reposar en su colchón de plumas, «la extremidad abdominal distensa». El naturalismo que la anécdota poética adopta estriba, pues, en una actitud, aquí reducida a su esencia: dejando a un lado el «buen gusto», el poeta satírico de «Consulta crítica» no rehúye la unión de voliciones y «fisiología», o de la cotidianidad más pura y circunstancial (aunque no sea de buen tono), con el fin de la sátira: la condena, y cómica persecución, de la mala literatura. Por encima de todo está el deber quijotesco del crítico, aunque tenga que escarmentar al destajista metido a dramaturgo y desairar al colega que le recomienda.

Más allá de posibles alusiones autobiográficas (Leopoldo Alas, crítico profesional, novelista y dramaturgo, murió, con 49 años, de una tuberculosis intestinal ${ }^{54}$ ), el humor es, claro está, verbal. De ahí la explicación primera, que canaliza otra de las vertientes de la burla, en conexión con la ya señalada. Me refiero al «lemosín de Cheste», lengua en la que supuestamente estaría compuesta la larga y extraña tirada de endecasílabos. En principio, el lemosín es una variedad lingüística, propia del área occitana, del subgrupo galo-íberoromance. En el área citada se hablan, además del lemosín, el aranés, el auvernés, el bearnés, el gascón, el languedociano y el provenzal. El lemosín se localiza en la provincia francesa de Limousin, con diferencias entre el bajo y el alto. Hasta

\footnotetext{
53 «Si las novelas de Zola no son detestables y aburridas es porque los preceptos del autor van por un lado, y su pluma, cuando es novelista y no crítico, va por otro. [...] Zola nada enseña, pues no ha de llamarse enseñar el poner a la vista vicios e indecencias nauseabundas [...]. Si Nana es una novela que tiene valor, no es, pues, por su enseñanza pornográfica, sino porque imita bien la naturaleza...». Carta-prólogo a Odas..., op. cit., pp. XXI-XXII.

54 Juan Antonio Cabezas, op. cit., pp. 221-222. Son repetidas las menciones de sus molestias abdominales, bien en su correspondencia personal o en el yo narrativo de su propia obra creativa. Vid. del mismo J. A. Cabezas, «Los últimos días de Clarín», en «Clarín» y «La Regenta» en su tiempo..., op. cit., pp. 25-32; y José María Izquierdo Rojo, «Historia clínica de Leopoldo Alas», ibídem, pp. 177-193.
} 
aquí la clasificación científica actual 55 . Clarín no se atiene a ella. En su mención se mezclan un uso culto de la época — el lemosín como paradigma de una cultura refinada que aunaba en el pasado el provenzal y el catalán-y, a la vez, una denominación ennoblecedora de la modalidad valenciana del catalán ${ }^{56}$. En su Florilegio de poesías castellanas del XIX Valera antologaba una de Milá y Fontanals significativamente titulada «El lenguaje lemosín»:

\author{
¿Por qué no nací en los días \\ de las glorias catalanas \\ cuando el habla lemosina \\ del poder y honor fue el habla? \\ ¡Ay! Marchito quedó el brillo \\ de la lira de Occitania, \\ mustia la violeta de oro \\ y rota la áurea cigarra. [...] \\ Ya no más lais y tensiones \\ de los maestros del arpa, \\ que los campos recorrían \\ seguidos de turbas gayas. [...]
}

\begin{abstract}
55 Para más precisiones, Juan Carlos Moreno Cabrera, El universo de las lenguas. Clasificación, denominación, situación, tipología, historia y bibliografía de las lenguas, Madrid, Castalia, 2003, pp. 187188, 195 y 205.

56 Valgan tres ejemplos del persistente uso de lemosín como 'valenciano' o, más genéricamente, 'catalán': 1) J. Justiniano, traductor de J. L. Vives, habla de un obispo de Barcelona que «escriuió en lemosí, que es un lenguage allá por sí entre Catalán y Vascón [i. e., 'gascón', no «vasco», como actualiza una editora moderna], que entonces se usaua por estos reinos de Valencia y Cataluña» (en su prólogo al Libro llamado Instrución de la muger christiana, el qual contiene cómo se ha de criar una virgen hasta casarla, y después de casada cómo ha de regir su casa; y biuir prósperamente con su marido, y si fuere biuda lo que es tenida a hazer. Traducido aora nueuamente de latín en romance por Juan Justiniano..., Valencia, Jorge Costilla, 1528, fol. IIIr.); 2) Traducción al castellano de la Escritura de concordia, en latín y lemosín, otorgadas [sic] entre las villas de Burriana y Nules sobre aguas para el riego, con fecha 28 de julio de 1662, ante Antonio Ferrer, notario de Valencia, sancionada en forma de privilegio por el rey Felipe IV en 18 de diciembre del mismo año, Valencia, Hijos de F. Armengol, 1963; 3) Patronato de la Festa (ed.), Lo Misteri d'Elig. El Misterio de Elche. Manual del curioso espectador de la representación de la famosa fiesta, compuesto para que sirva de guía y claro conocimiento. Autores escogidos, D. Gaspar Soler Chacón, del texto lemosín; D. Claudiano Phelipe Perpiñán, de la traducción, Valencia, Renovación Tipográfica, 1933. Una de las copias en «lemosín» de Lo Misteri d'Elig fue proporcionada por Barbieri, pero según los editores perteneció al marqués de Molins (p. 32), tan unido por amistad al conde de Cheste.
\end{abstract}




\author{
Del saber el noble cetro \\ que el catalán empuñaba \\ cayó también de su diestra \\ al olvidarse su habla. $[\ldots]^{57}$
}

En esta reivindicación romántica de un pasado glorioso Occitania y Cataluña brillan unidas culturalmente bajo un sol de plenitud.

Clarín, que no debatía problemas lingüísticos ni de historia literaria, acudió al lemosín como imagen de una lengua arcaica y desusada. Es posible que en su aplicación del término hubiera, además, un juicio de intenciones más complejo. Rubió y Lluch ha señalado con su autoridad que entre los nombres que a lo largo del tiempo se han dado al catalán, no hay ninguno «más inexacto e inadecuado, más destituido de todo fundamento histórico y filológico» que el de lemosín, ya usado con esa acepción en el siglo XIV. El lemosinismo, añade, es una «verdadera obsesión en los países del Levante de España», sobre todo en el antiguo reino de Valencia. Jovellanos y Menéndez Pelayo manifestaron un criterio disconforme con un uso tan arraigado. Ampliando el marco, el segundo definió como «peregrina denominación» la de lemosín o provenzal para el catalán, llegando a calificar de majaderos («de Castilla y aun fuera de ella») a los que llamaban trobas lemosinas a los versos compuestos en lengua catalana ${ }^{58}$.

Rubió y Lluch señala, no obstante, que el bautizo arraigó también en Cataluña, como demuestra el poema que he citado de Milá y Fontanals. En la llamada llengua llemosina habrían sido escritas, por tanto, páginas gloriosas de Aribau, de Rubió y Ors o de Piferrer. Razonaba el gran historiador catalán:

Nada tiene de extraño, pues, que al evocar los padres de la Renaixensa nuestro pasado literario, renovaran el recuerdo de los gloriosos trovadores, y que, al estudiar los eruditos los viejos textos del patrio idioma, se sintieran ganados por el hechizo de aquella palabra, dulce y graciosa, que creían que, a la vez que ennoblecía el habla vulgar, aplebeyada por el descuido y la ignorancia, había de hacerla más simpática a los ojos de los

\footnotetext{
${ }^{57}$ Juan Valera, Florilegio..., t. II, 1902, pp. 246-247. Historiando la época de Carlos V, había escrito Sismonde de Sismondi: «El lemosín o provenzal, que aún se conservaba en las chancillerías de los estados de Aragón, y que era el dialecto del pueblo, fue abandonado por los escritores y poetas para abrazar el lenguaje de la corte». Historia de la literatura española desde mediados del siglo XII hasta nuestros días, dividida en lecciones..., traducida y completada por José Lorenzo Figueroa, Sevilla, Imp. de Álvarez y Cía., 1841-1842, 2 vols.; I, p. 200. Para lemosín, véase también la Enciclopedia universal..., s. v.

58 Antonio Rubió y Lluch, «Del nombre y de la unidad literaria de la lengua catalana», en Discursos leídos ante la Real Academia Española en la recepción pública del Sr. D. Antonio Rubió y Lluch el día 23 de marzo de 1930, Barcelona, Imprenta de Ángel Ortega, 1930. Las citas de M. Pelayo (p. 12, n. 7) son de 1888 y 1889. Hay reedición moderna del discurso, con prólogo y notas del lingüista valenciano Germà Colón Doménech, Barcelona, Institut d’Estudis Catalans, 2004.
} 
que la despreciaban y la relegaban al olvido. Así reapareció el nombre de lemosín en aquel canto evocador de Aribau que los catalanes hemos persistido en bautizar con el título de Oda a la Patria... ${ }^{59}$

Acorde o no con Menéndez Pelayo, Clarín enjuicia desde esa misma tradición del XIX, propia de catalanes y valencianos, pero propia también de una reivindicación regionalista de mitos fundacionales. Y dado que su postura es crítica y satírica, hemos de pensar que para él lemosín, como lengua de Cheste, encierra varias ironías. Entraría en juego, por de pronto, la alusión al conde como capitán general de Cataluña, pero también la condición de Cheste como villa de Valencia. En un plano cultural más profundo, el lemosín de Cheste - es decir, el español escrito por don Juan de la Pezuela- sería una lengua impostada y falsa, reinvención arcaizante y cultista fabricada sin tino ni criterio.

Cabe precisar desde nuevas perspectivas. En otras páginas de Nueva campaña Cheste es calificado burlescamente como "políglota en castellano». Es con motivo de la reseña de una novela del carlista y reaccionario Ceferino Suárez Bravo («alias Ovidio el Romo», según Clarín ${ }^{60}$ ), novela que había sido premiada por la Real Academia Española. El catedrático de Oviedo, que no paraba en barras, se burlaba una vez más de la docta corporación, de su presidente y selectos compañeros de armas. Apartados unos cuantos nombres (los «moros» de su relato), describía así una sesión académica semejante a aquella en que se decidió el premio:

Le sucede a la Academia lo contrario de lo que la Iglesia dice que le pasa a ella. El Espíritu Santo inspira a los cristianos, por lo menos a los obispos, en cuanto se juntan; y a los académicos en corporación les quita el talento que tienen muchos de ellos. Es decir, que allí parece que mandan la minoría, no la liberal, sino la minoría de los malos y de los pésimos. Molins y mi tocayo el del Cueto, dramaturgo adocenado; Arnao y Barrantes, el tedio de las Musas; Casa Valencia, senador del reino; Tejado, lleno de goteras; Balaguer, inmortal, y el amarillo Catalina (o jaramago), no son más que nueve, y aunque se les añada al de Cheste, políglota en castellano, y a Mir, jesuita electo, y a Pidal mayor, jefe de su familia, no pasan de doce; y

\footnotetext{
59 Ibídem, p. 14.

${ }^{60}$ En «palique» de Madrid Cómico, 118, 24-V-1885; luego, en Nueva Campaña..., p. 41; y Paliques, ed. cit., p. 206. El apodo «explica» el seudónimo del propio escritor (1824-1896), que firmaba como Ovidio sus colaboraciones en El Siglo Futuro. Clarín juega, claro es, con Ovidio Nasón para aludir a la chatura intelectual de este asturiano. J. $\mathrm{M}^{\mathrm{a}}$ Martínez Cachero, «Algunas noticias para la biobibliografía de Ceferino Suárez Bravo», Boletín del Instituto de Estudios Asturianos, 9 (1950) pp. 4963; y «Más noticias para la bio-bibliografía de Ceferino Suárez Bravo» en BIEA, 40 (1960), pp. 195216; ahora en El canto de las sirenas (páginas de investigación y crítica), Oviedo, Universidad, 2000, pp. 505-552, y Biblioteca Virtual Cervantes.
} 
aun suponiendo que el de la Pezuela valga por dos, son a lo sumo trece (la docena del fraile). ¿Cómo, siendo trece los malos y más los otros, el mal triunfa en la Academia? ¡Ay! Es porque, al votar, los académicos no se dividen en malos y buenos, sino en moros y cristianos $^{61}$. $\mathrm{Y}$ los moros, como saben que están en minoría, no suelen ir siquiera a la calle de Valverde ${ }^{62}$.

Al decir humorístico de Clarín, el de la Pezuela (marqués) o el de Cheste (conde) podía valer por dos, pero uno y el mismo escribían, sin duda alguna, en «lemosín». El juicio, así resumido por el crítico ovetense, quizá ya resonaba en alguno de los agrios periódicos de la época desde 1868, el año de la Gloriosa y del destronamiento de Isabel II. Antes de los sucesos revolucionarios, en enero, el periódico ultracatólico La Constancia, vespertino dirigido por Cándido Nocedal, ofrecía muestras de la traducción de Dante, con cantos del Paradiso en tercetos castellanos firmados a su fin por «Juan de la Pezuela, Conde de Cheste»63. En el mismo año un folleto adelantaba, en bilingüe y con cuidada tipografía, el canto XXV del Inferno ${ }^{64}$. El traductor había hecho el esfuerzo de preservar metro, estrofa y número de versos, pero no había tenido empacho en cuadrar rimas y encadenar tercetos con la más ripiosa libertad. Lo mismo casaba

61 Distinción con la que había jugado en «El libro de Menéndez Pelayo. Breve examen de los últimos capítulos de los Heterodoxos españoles», El Progreso, 543, 30-X-1882; OC, VII, op. cit., pp. $162-$ 166 (más sucesivas entregas). Criticaba allí el orden expositivo del autor: «Porque no me dirá mi ilustre amigo que es orden serio el de dividir a los escritores en moros y cristianos para hacer que los cristianos derroten a los moros, sin excepción de un solo turbante. Y eso es lo que hace él» (p. 165). Tenía, pues, su chufla incluir a Pelayo entre los moros, junto con Castelar o Valera.

62 «Guerra sin cuartel. Novela original de don Ceferino Suárez Bravo, premiada por la Real Academia Española», Madrid Cómico, 24-X, 7-XI y 14-XII-1885; Nueva campaña..., pp. 171-186; p. 173. La lista de académicos aludidos es la siguiente: Mariano Roca de Togores y Carrasco, Marqués de Molins (1812-1889), Leopoldo Augusto de Cueto, Marqués de Valmar (1815-1900), Antonio Arnao (1828-1889), Vicente Barrantes (1829-1898), Emilio Alcalá Galiano y Valencia, Conde de Casa Valencia (1831-1914), Gabino Tejado y Rodríguez (1819-1891), Víctor Balaguer (1824-1901), Mariano Catalina (1842-1913), cruelmente asimilado a un verso de Rodrigo Caro en su célebre «A las ruinas de Itálica»: «...publica el amarillo jaramago...»; P. Miguel Mir (1841-1912), Alejandro Pidal y Mon (1846-1913). Las cuentas de Clarín no salen: con Cheste son 11 (ó 12), no 13. A la calle de Valverde, donde la RAE ocupaba el edificio del antiguo Estanco del Aguardiente (lo que haría de 1794 a 1894), no se habrían acercado para votar ni Castelar, ni Menéndez Pelayo, Campoamor, Núñez de Arce, Echegaray, Valera, Tamayo o Alarcón, aludidos al comienzo del mismo artículo. Clarín se equivocaba, pues los impulsores del premio fueron M. Pelayo y Manuel Cañete, con desacuerdo y protesta de Pereda en carta a su paisano (J. M Martínez Cachero, Menéndez Pelayo y Asturias, Oviedo, Instituto de Estudios Asturianos, 1956, pp. 205-206). Sobre el edificio de la calle Valverde, Alonso Zamora Vicente, La Real Academia Española, Madrid, Espasa-Calpe, 1999, p. 50. 63 «La Divina Comedia de Dante», Paraíso, VI, 14-I-1868; VIII, 16-I-1868; XII, 24-I-1868; Infierno, III, 6II-1868... Reúno estos datos incompletos de prensa a título puramente indicativo.

64 Canto XXV del Infierno de Dante, traducido en verso castellano por el Capitán General D. Juan de la Pezuela, Conde de Cheste, de la Real Academia Española, Madrid, Imprenta de Manuel Tello, 1868. 
acerbo, protervo y superbo (Infierno, XXV), que leticia, justicia y nequicia (en su Paraíso, canto VI), o sustancia, andancia y distancia (ibídem, canto VIII). Aunque todos esos términos figuraban y figuran en el conservador y respetuoso Diccionario de la Real Academia Española, es claro que el esforzado don Juan de la Pezuela no gozaba ni de un oído sublime ni de un tino idiomático digno de envidia (o de palmas académicas). Muestra de ello es que tampoco dudaba en aclimatar al terceto encadenado italianismos en crudo, como muso o zavorra, creando tercetos de tanta torpeza como el siguiente:

$$
\begin{aligned}
& \text { El caído adelante saca el muso, } \\
& \text { y las orejas hunde en la cabeza } \\
& \text { cual caracol los cuernos pone en uso. }
\end{aligned}
$$

En los versos equivalentes del canto XXV de su Inferno Dante está describiendo la metamorfosis del cuerpo de un condenado, que poco a poco adquiere forma de serpiente:

Quel che giaceva, il muso innanzi caccia,

e gli orecchi ritira per la testa,

come face le corna la lumaccia ${ }^{65}$.

Cayetano Rosell, que se adelantó con una versión en prosa a la del conde de Cheste, tradujo de este modo: "Mas el que yacía en tierra prolongó la faz hacia delante y escondió las orejas dentro de la cabeza, como el caracol esconde los cuernos»66. Muso es, más bien, 'hocico, morro', pero puede ser también 'bocca, zona labiale', o 'viso, volto, faccia di una persona', entre otras acepciones ${ }^{67}$. Forzando de nuevo modo las rimas, Ángel Crespo ha traducido:

El que yacía el rostro adelantaba, sumiendo las orejas en la testa: del caracol los cuernos imitaba ${ }^{68}$.

\footnotetext{
65 Infierno, canto XXV, ibídem.

${ }^{66}$ Dante Alighieri, La divina comedia, según el texto de las ediciones más autorizadas y correctas. Nueva traducción directa del italiano por don Cayetano Rosell, completamente anotada y con un prólogo biográfico-crítico, escrito por el muy ilustre presidente de la Real Academia Española D. Juan Eugenio Hartzenbusch, ilustrada por Gustavo Doré, Barcelona, Montaner y Simón, 1870, 2 vols.; I, p. 166.

${ }^{67} \mathrm{Vid}$. Salvatore Bataglia, Grande dizionario della lingua italiana, Torino, Unione Tipografico-Editrice Torinese, 1981, t. XI, s. v.

68 Divina comedia, ilustrada por Miquel Barceló, ed. bilingüe, trad. y notas Ángel Crespo, Barcelona, Círculo de Lectores, 2002, Infierno, canto XXV, p. 168. Véase también Divina comedia, ed. Giorgio Petrocchi, trad. y notas de Luis Martínez de Merlo, con un apéndice sobre «Dante en España» de Joaquín Arce, Madrid, Cátedra, 1988, p. 229. Una posible versión sin rima final: «El
} 
El terceto no es mucho más feliz, pero se entiende mejor el proceso descrito por el poeta florentino. «Sacar el muso», como escribía el capitán general, parece invención de arroyo, una construcción de las que tanto habrían de agradar al Valle-Inclán de Luces de bohemia o de El ruedo ibérico, del estilo de «estirar la gaita» o «aventurar la jeta», por jugar con ejemplos hipotéticos; en todo caso, lo más opuesto al sentido del endecasílabo dantesco. Y no se piense que el terceto elegido es una excepción en la habilidad del versificador y traductor, pues aquí es una triste verdad lo del solo botón que puede servir de muestra69. La ironía clariniana tiene razón de ser: «políglota en castellano».

Pero el lemosín merece más precisiones. Es el mismo Clarín quien las hace poco tiempo después en un aparte de uno de los capítulos que tributa a Cánovas —Cánovas historiador»—en el Folleto que le dedica en 1887:

Conviene comenzar este capítulo advirtiendo a los papanatas que no es lo mismo historiador que presidente de la Academia de la Historia. También Cheste preside la Academia de la Lengua y no tiene lengua; quiero decir, que tiene la lengua presa y habla un demonio de lemosín cultilatino, que recuerda aquella alalogia de los primeros cristianos $^{70}$.

Alalogia, neologismo del catedrático de Oviedo, sería «mudez del logos», es decir, ininteligibilidad del pensamiento, sin duda por su carencia ${ }^{71}$; pero carencia, en este caso, oculta o disimulada por el mismo discurso, disfrazado de «lemosín cultilatino». La similitud con el habla de los primeros cristianos está traída por los pelos, y solo un pasaje posterior del mismo Alas sugiere la fuente vagamente recordada por el escritor en este primer momento. El segundo, referente a la «glosolalia» de los bendecidos por el don de lenguas, tiene lugar

que yacía prolongó la boca / y, como el caracol que hunde los cuernos, / retrajo en su cabeza las orejas».

69 En el mismo canto «zavorra» («la settima zavorra») es castellanizado como «zaborra», según terceto ya citado: «Así vide en la sétima zaborra...» (Cosí vid'io la settima zavorra / mutare $e$ trasmutare; e qui mi scusi / la novità se fior la penna aborra). C. Rosell, que aventuraba "sentina», explicaba: «Zavorra es la mezcla de guijo y arena que se mete para lastre en las embarcaciones. Aquí se toma por el lugar en que pasa la escena, por el sétimo foso» (p. 166). Salvatore Bataglia, tras la primera acepción, añade: «Fig. I damnnati di una bolgia dell'Inferno dantesco» (GDLI, t. XXI, s. v.). A. Crespo usa «zahorra», opción legítima (ed. cit., p. 168); y L. Martínez de Merlo prefiere la libertad de «zahúrda»: «Así vi yo la séptima zahúrda / mutar y transmutar; y aquí me excuse / la novedad si oscura fue la pluma» (p. 230).

70 Folletos literarios, II: Cánovas y su tiempo (primera parte), Madrid, Librería de Fernando Fe, 1887, pp. 67-68.

${ }^{71}$ El español, como el inglés o el italiano, admite alalia, término médico y helenizante que define la 'pérdida del lenguaje producida por una afección local de los órganos vocales'; de ahí álalo (o alalo), con la misma alfa privativa. No he hallado alalogia ni en alemán ni en francés, ni en ninguna de las otras tres lenguas citadas. 
en otro de los Folletos literarios, el IV, cuya segunda parte fue dedicada a Un discurso de Núñez de Arce. Recordaría allí Clarín un pasaje de una epístola de San Pablo a los corintios:

Cuando los cristianos del primer siglo se entusiasmaban con sus facultades extraordinarias de lenguaje universal, que estaba cifrado en la glosolalia - modo de hacerse entender de todos a fuerza de no explicarse para nadie-, el apóstol de los gentiles, sin duda gran partidario de la prosa, advertía a sus hermanos que la tal glosolalia era buena para ejercitada a solas; pero que, cuando hubiese gente delante, el glosolalo debía hacerse traducir por algún intérprete, esto es, por un prosista, en el sentido lato de la palabra ${ }^{72}$.

Pese a las diferencias, la ironía de Clarín atañe a los dos términos: la glosolalia y la alalogia, que se vuelven sinónimos en el efecto provocado: la ininteligibilidad, pues el ovetense no confunde el hablar inspirado, pero confuso, del glosolalo con el dominio milagroso que, sin necesidad de aprendizaje, pudiera ejercer el dotado de xenoglosia o xenolalia ${ }^{73}$. Ante el caso del presidente de la Real Academia el problema era mucho más simple: el conde de Cheste, venía a decir Clarín, desconocía simplemente la lengua cuya limpieza, fijeza y esplendor le había sido oficialmente encomendada, habiéndose inventado una para su exclusivo uso: el lemosín cultilatino o cultidiablesco.

\section{IV}

No extraña que aquella traducción de La divina comedia necesitara presentación y defensa a la hora de aparecer en libro, sobre todo si añadimos el contexto histórico de la época, cuando la llamada cuestión romana, que afectaba a todos los católicos del mundo, llevaba a la lectura político-religiosa del poema dantesco. No ha de olvidarse que en 1871 Roma fue declarada capital de la Italia unificada, con la cerrada oposición de Pío IX, que se constituyó prisionero en el Vaticano y rechazó la pérdida del poder temporal del papado. En notas clarinianas de El Solfeo se podía leer: "Cartas peregrinas, y exclamaciones idem: “¡Ay de Roma, el día en que el Pontífice, hoy prisionero!...” ¡Así se escribe la historia!» Y en párrafo contiguo, del mismo periódico y día: «"El papa, después de recibir de los peregrinos catalanes las ofrendas en oro, recogidas por los redactores de los periódicos católicos, recomendó la perseverancia...". Se

72 Folletos literarios, IV: Mis plagios. Un discurso de Núñez de Arce, Madrid, Librería de Fernando Fe, 1888, p. 115. Alude a San Pablo, I, Cor., XIV, 13-14, 27-28.

73 Para los distintos conceptos y su historia, vid. Elena del Río Parra, «Babel y barroco: "hablar en lenguas" y otras manifestaciones teolingüísticas áureas», RFE, LXXXV, $1^{\circ}$ (2005), pp. 27-47. 
comprende perfectamente» 74 . Dante había condenado por simoníacos, retratándoles en el infierno, a Bonifacio VIII y su sucesor en el solio pontificio Clemente V (Inf. XIX, 52-54). Condenas de este tipo podían ser leídas por alguien, malévolamente, sobre el trasfondo del día.

De defender la ortodoxia de Dante y la legitimidad del traductor se encargó Mariano Roca de Togores, marqués de Molins, quien firmó el largo prólogo a los tres cuidados volúmenes que en 1879 vieron al fin la luz con la versión completa de la Comedia. Es probable que el libro hubiera estado dispuesto para su edición en 1868, pues el prólogo está firmado en enero de ese convulso año. Si fue así, los hechos revolucionarios, con el peso añadido de los escrúpulos religiosos, habrían impuesto una larga demora ${ }^{75}$. En portada el conde de Cheste hacía constar su condición de capitán general, cargo que entonces ostentaba en Cataluña. Ya era también, desde 1875, presidente de la Real Academia de la Lengua. Las bases del edificio dantesco en versión española eran aún más sólidas, pues el marqués de Molins había ocupado el mismo sillón de director desde 1865, cargo en el que le sucedería el de Cheste ${ }^{76}$.

Si nos ceñimos al campo estrictamente literario, es probable que los vientos contrarios a aquella traducción fueran avivados por el mismo Roca de Togores. Es claro que no hubo ni un átomo de mala intención contra el compañero y amigo, pero las observaciones que deslizó al fin de su prólogo sobre las licencias poéticas del traductor quizás no hicieron más que alimentar la opinión desfavorable que ya se había formado. El marqués de Molins refería cómo había ido conociendo la versión de Dante en la tertulia literaria que se reunía en su casa, y cómo la había defendido antes de su edición definitiva. Incluso decía haber ganado apuestas en esa defensa de la legitimidad del léxico de la traducción. Añadía después:

Los vocablos que usa todos están consignados en nuestros diccionarios; todos, o la mayor parte, usados por autoridades respetables. [...] estas voces usadas por el traductor nos parecen un ingeniosísimo medio para darnos a conocer íntegra y completamente aquel autor, semibárbaro según unos, semidivino según otros, que no solo empleó en su poema voces de su creación, sino que mezcló con el recién nacido lenguaje de Italia el latín, el griego, el árabe, el siríaco y hasta palabras no comprendidas todavía, como las que dicen Pluto y Nembrod ${ }^{77}$.

\footnotetext{
74 El Solfeo, 21-X-1876.

75 El marqués de Rozalejo, sin duda a través de los descendientes de Cheste, interpreta que este, «temiendo dar el menor aliento a los enemigos de la Iglesia, reservó publicar la traducción hasta el año 79», cuando ya había muerto Pío Ix (op. cit., p. 199).

76 A. Zamora Vicente, op. cit., pp. 165-166.

77 De la introducción, op. cit., pp. 106-107.
} 
«Lancero de los bosques, Nemrod que todo caza», habría de llamar Rubén Darío en un soneto juvenil al caudillo araucano Caupolicán ( $2^{\mathrm{a}}$ edición de $A z u l . . ., 1890)$, lo mismo que consideraría a Roosevelt, en sus Cantos de vida y esperanza (1905), "primitivo y moderno, sencillo y complicado, / con un algo de Washington y cuatro de Nemrod»78; un Darío que lo mismo habría de renovar en español el recuerdo del Nemrod bíblico que dar carta de naturaleza poética a la rara «clepsidra», reloj de agua que cuenta las horas con goteante e isócrona lentitud. Son, entre otros muchos, términos que (no ignorados de antes ${ }^{79}$ ) se incorporarán a la lengua literaria con la revolución modernista. El conde de Cheste no tuvo esas virtudes de poeta, y su nequicia o 'perversidad' literaria fue notoria, como le señalaron, incluso con chusca crueldad, algunos de sus lectores. Así lo hizo un prolífico libretista de zarzuela, Salvador María Granés (o Moscatel), que en un libro de retratos en verso trazó este del conde de Cheste:

De oficial en adelante

hizo siempre buen papel;

el hecho más culminante

que puede contarse de él

es la ejecución de Dante ${ }^{80}$.

El no tan dulce Moscatel tendría escasa simpatía por el tándem académico, a juzgar por esta segunda quintilla, en el mismo libro, sobre el prologuista de la ejecución:
Molins es un caballero;
como hombre, poco simpático;
como literato, huero;
malo como diplomático;
y como ministro, cero $^{81}$.

\footnotetext{
78 En «Roosevelt en París» también le llama «el jovial Nemrod». En Todo al vuelo, Madrid, Renacimiento, 1912, p. 153.

79 Antonio Enríquez Gómez, p. e., suscribe una Soberbia de Nembrot, comedia famosa; y Alonso Jerónimo de Salas Barbadillo incluye en sus Rimas castellanas un soneto «A Nemrot»: «¿Por qué con atención tan atrevida...?» (Madrid, Viuda de Alonso Martín, 1618, f. 18v).

80 Salvador M. Granés («Moscatel»), Calabazas y cabezas, semblanzas de personajes, personas y personillas que figuran o quieren figurar en política, literatura, armas, ciencias o tauromaquia, escritas en verso... e ilustradas con caricaturas de Perea y Luque, con una carta-prólogo de Manuel de Palacio, Madrid, M. Romero, 1880, p. Ya lo cita A. Zamora Vicente, op. cit., pp. 515-516. Según el Marqués de Rozalejo [Antonio de Urbina], Cheste fue atacado por los jóvenes como «el danticida», pero elogiado en este terreno por Valera (Cheste o todo un siglo..., pp. 285-286). El elogio, como luego indicaré, fue muy restrictivo.

81 Ibídem, p. 88.
} 
Igual de contundente, pero más acre, fue Antonio de Valbuena, imitador (sin su agudeza) de Clarín, que en un volumen de Ripios aristocráticos, dedicado a revisar críticamente la obra de los muchos poetas con título nobiliario de la sociedad del momento, arremetía en dos capítulos contra el de Cheste ${ }^{82}$. El libro, que tuvo una segunda edición en el mismo año, reunía artículos antes aparecidos en la prensa, de lo que cabe deducir su éxito. En la primera página Venancio González (seudónimo bajo el que se escondía Valbuena) asentaba un principio, luego incumplido: «Ni menos voy a hablar del señor Marqués de la Pezuela, que así se llama o se ha llamado también el conde de Cheste, el cual podrá ser muy mediano general, pero desde luego es muy mal poeta». Refiriéndose luego a los tercetos dantescos, y solo con apoyo en un recorte de $\mathrm{La}$ Constancia (decía no necesitar más), Valbuena hablaba de «logogrifos ininteligibles» $\mathrm{y}$ «conceptuosa oscuridad académica»83.

Clarín no sería más piadoso. Muchas son en sus artículos las alusiones, muchos los desprecios, como en estas tempranas líneas del periódico satírico El Solfeo: «Mire V. E. que una cosa es ser Conde de Cheste y otra cosa es ser poeta, y que si a V. E. le ha soplado la musa por el condado, no le sucede lo mismo con la poesía, ni siquiera con el hermoso idioma español, que V. E. trata despiadadamente a cintarazo limpio, o a plumada, que es igual»84. En el año en que al fin aparece la edición en tres volúmenes de La divina comedia, con el prólogo de Molins, el ovetense dictaminaba que el de Cheste «sigue triturando versos del Dante con una majestad y una frescura que no tienen ejemplo» 85 . En 1885 escribiría, ahora en un «palique» de La Ilustración Ibérica: «Dante convertido en ese salchichón que se llama los tercetos de Cheste es más indigesto que la langosta cruda». Esta frase brotaba al hilo de uno de los célebres banquetes que el director de la Academia dispensaba en su casa de la calle Pizarro, en este caso «en obsequio» de una poetisa malagueña, la señorita Josefa Ugarte-Barrientos y Casaux, futura condesa de Parcent. Clarín callaba el nombre, pero daba las señas: «La poetisa es guapa, yo la he visto en Málaga. Los versos no se los

\footnotetext{
82 «Venancio González», Ripios aristocráticos, Madrid, Tipografía Hispano-Americana, 1884, pp. 2735 y $59-66$.

83 Ibídem, p. 66. En 1897 un nuevo traductor de Dante, nada menos que Bartolomé Mitre, se hacía eco en Buenos Aires de los antiguos juicios: «La [versión] del general Pezuela, elogiada por sus amigos, ha sido justamente criticada en la misma España, por inarmónica como obra métrica, enrevesada por su fraseo y bastarda por su lenguaje. Sin ser absolutamente infiel, es una versión contrahecha, cuando no remendona, cuya lectura es ingrata y ofende con frecuencia el buen gusto y el buen sentido. Es como la escoria de oro puro, primorosamente cincelado, que se ha derretido en un crisol grosero». La divina comedia, traducción en verso, ajustada al original, con nuevos comentarios, Buenos Aires, Jacobo Peuser, 1897, $2^{\mathrm{a}}$ ed. definitiva, p. XVI.

84 «Notas y notitas», 9-XI-1876. La sección aparecía sin firma, pero sus notas, apuntes, coplas, aleluyas, aforismos, etc., solo excepcionalmente no son de Clarín.

${ }^{85}$ La Unión, 213 (15-V-1879), en Paliques, ed. cit., p. 48.
} 
conozco. Pero conozco a Cheste. ¿Quién le manda andar diciendo en los periódicos los comensales que tiene? ¿Qué le importa al pueblo español, al noble y hambriento pueblo español, saber con quién come el Anti-Dante?»86. Sabemos por La Correspondencia que los aludidos comensales eran Alarcón, Balaguer, Campoamor, Guerra y Orbe, Menéndez Pelayo, Núñez de Arce, Tamayo y Baus..., es decir, miembros todos de la Real Academia en torno a la blonda poetisa malacitana; sabemos también que hubo al fin velada literaria con recital de versos, entre ellos «una trova provenzal, escrita por la distinguida dama a quien se dedicaba la fiesta, y que acaba de ser premiada por la academia de Juegos Florales de Tolosa, siendo la primera poesía castellana por ella premiada»87. La aludida trova, que había recibido la honrosa distinción en 1883, llevaba el título de «El serventesio», y en ella se mezclaban las barras de Cataluña, «la patria provenzal», la Edad Media y los trovadores ${ }^{88}$. Los brillos del lemosín no andaban, pues, muy lejos, en una imprecisa región que se situaba entre Tolosa de Francia y el antiguo reino de Valencia. No extraña que Balaguer, uno de los impulsores de la Renaisença catalana, que en uno de sus poemas se definía a sí mismo como «trovador errante» 89 , leyera aquella noche la composición por su propia voz en la noble casa del conde de Cheste.

Por el mismo tiempo Clarín hizo campaña a favor de la concesión de una pensión vitalicia y anual a José Zorrilla de 30.000 reales, escandalizado porque seis «padrastros» de la patria, miembros de la Real Academia, habían votado en contra del viejo y prestigioso poeta. Recorriendo títulos y dignidades, arremetía de este modo:

86 La Ilustración Ibérica, 127, 6-VI-1885; y Paliques, ed. cit., p. 208. La aludida J. Ugarte-Barrientos (1854-1891) se casaría en 1887 con Fernando de la Cerda, conde de Parcent y de Contamina, grande de España. Vid. María Isabel Jiménez Morales, Escritoras malagueñas del siglo XIX, Málaga, Universidad, 1996, pp. 110-122 y 270-220. Otro palique burlesco sobre la reseña de un banquete de Cheste por La Época, en Madrid Cómico, 203 (8-I-1887); Paliques, ibídem, p. 234.

$87 \mathrm{La}$ Correspondencia de España, 20-IV-1885, con lista parcial de asistentes. Leyeron versos «la señorita Ugarte-Barrientos y los señores conde de Cheste, Alarcón, Menéndez Pelayo, Núñez de Arce y Balaguer». Cheste, ya de 75 años, había publicado un romance «A la ilustre poetisa malagueña Srta. Dña. Josefa Ugarte-Barrientos», Revista Malacitana, I, 8 (22-III-1885), pp. 58-59: «De quince lustros muy largos / ya el duro peso me postra...». Póstumamente aparecen, de la condesa, unas Poesías selectas, con un soneto-prólogo del Excmo. Sr. Conde de Cheste y un proemio de Pedro de Répide, Málaga, Tip. «La Ibérica», s. a. [¿1904?]. Al pie del soneto se reproduce un autógrafo de letra temblorosa: «En Madrid el 24 de abril de 1903 escribió estas líneas a los 94 años de su edad Juan de la Pezuela, Conde de Cheste».

${ }^{88} \mathrm{El}$ premio se declara expresamente en la primera edición del poema, Revista Malacitana, I, 6 (8III-1885), p. 43 (Fundación Unicaja · Archivo Díaz de Escovar - Málaga); y en Poesías selectas, op. cit., pp. 155-157.

89 «En el álbum de la Excma. Sra. Marquesa de la Pezuela», Celistias. Poesías, Madrid, Imp. de la Viuda de M. Minuesa de los Ríos, 1895, pp. 152-153. 
Eso sí; mucho Conde de Cheste, Marqués de la Pezuela, o al revés, o no sé cómo, ni me importa, dignidad de Clavero Mayor (y no ha dado una en el clavo, tan viejo como es), individuo de la de los (¿en qué quedamos?) Árcades en Roma (como si hubiera Arcadia posible donde esté Pezuela), socio preeminente de la de Buenas Letras de Sevilla...; sí, sí, preeminente y promiscuante y protuberante y preeeesidente y AntiiiiiDante.

Para definir a Cheste y a Molins, ese Roca Togores de apellido y Roca Tarpeya de la poesía, tiene el Diccionario de la Academia palabras, palabras, palabras; y para definir a Dios no tiene más que estas: «Nombre sagrado del Supremo Ser [por no decir Ser Supremo], criador del Universo [¡qué sabe usted!], que lo conserva y rige por su providencia...» ¡Vaya una teología ramplona! Y gracias que la Academia no hace a Dios de la de los Árcades de Roma ${ }^{90}$.

La cruel burla iba contra la Academia en sí misma, por su Diccionario, y de modo especial contra dos de sus máximas figuras, unidas casualmente en el «danticidio». Del primero quedaban reídas su condición noble —marqués, conde (y grande de España)—, su alta pertenencia a una orden militar — con dignidad de clavero mayor-, su ya notada condición de árcade romano (bajo el nombre de Olmisto Isaurense, luego Chestense) y de socio, seguramente de honor, de la de Buenas Letras de Sevilla; lo era también de la de Barcelona, y había fundado la de Puerto Rico, además de ser senador por derecho propio y tener el toisón de oro ${ }^{91}$; la mordacidad contra el de Molins era menos intensa, aunque no menos hiriente; se acrece si atendemos al contexto (personal y global), que cabe deducir de unas palabras laudatorias de Juan Eugenio Hartzenbusch, las cuales dibujan un ancho panorama de títulos y relaciones:

El Excmo. Sr. D. Mariano Roca de Togores, Marqués de Molins, Vizconde de Rocamora, tercer hijo del Conde de Pinohermoso y de la Condesa de Villa-Leal, Grandes de España de primera clase, nació en Albacete, fue educado en Madrid en el colegio de la calle de San Mateo, en que profesaban Hermosilla y Lista, y de que fueron alumnos D. Ventura de la Vega, D. José de Espronceda, el señor Marqués de la Pezuela y otros individuos ilustres de la república de las letras; estudió más tarde en otro colegio sito en la calle Ancha de San Bernardo, de donde salieron

\footnotetext{
90 «Seis bolas negras!», Madrid Cómico, 24-V-1885; y en Nueva campaña (1885-1886), p. 42. Siguen otras arremetidas contra el DRAE. En la cita he cambiado los paréntesis por corchetes para distinguir con claridad las intervenciones clarinianas en el texto ajeno.

${ }^{91}$ Sobre los datos que reúne Clarín acumulo otros, pero advirtiendo que no todos coincidirían en el tiempo; valen aquí para subrayar la personalidad histórica de Cheste. Vid. Juan Valera, «Notas biográficas y críticas», op. cit., p. 1296a; y A. Zamora Vicente, op. cit., p. 246.
} 
igualmente D. Aureliano y D. Luis Fernández Guerra y Orbe, D. Carlos Doncel y algunos más de no inferior nombradía... ${ }^{92}$

El crítico literario y catedrático de Oviedo Leopoldo Carcía-Alas, que estaba a punto de publicar la primera parte de La Regenta93, se batía en las páginas de la prensa contra algunas de las figuras más destacadas de la Restauración. Se repartía incluso las Academias, si al nombre de Cheste añadimos el de Cánovas, presidente de la de Historia. Al margen del juicio literario, Clarín ejercía una oposición política, sin duda arriesgada. Lo único que podía protegerle era precisamente la peligrosa o expuesta trinchera desde la que atacaba.

Son de interés las reacciones de un testigo excepcional de toda esta trama y combates. El olímpico don Juan Valera, que ocupaba cargo diplomático en Lisboa y se carteaba ampliamente con el joven Menéndez Pelayo, charlaba con este sobre la recepción del libro de Odas, epístolas y tragedias, que él había prologado:

Todas mis alabanzas de los versos de usted están en su punto, no pecan de exageradas, sobre todo si se atiende al estilo hiperbólico que en España se emplea. [...] Por modestos que seamos, donde Sellés es un Shakespeare, bien puede usted ser un Píndaro y yo un Cervantes. [...]

Si yo no estuviese cansado y viejo, todavía había de emprender una tarea que fuese un libro con el tiempo: Crítica de la crítica en moda y defensa de las víctimas más ilustres. Cheste, Cánovas y Villahermosa habían de resultar setenta mil veces más poetas que Campoamor y que Grilo. Como que lo son, créamelo usted. —Solo que ahí todo está trabucado ${ }^{94}$.

En la intimidad de su correspondencia Valera no hizo otra cosa que quejarse de su indolencia o cansancio, mientras oteaba, leía y escribía, siempre con elegante agudeza y cierto desdén por las verdades crudas o la simple y llana estupidez. El quijotesco Clarín, con su verdad por delante, tenía que provocarle curiosidad y temor. Eran dos inteligencias de primer orden y de muy distinto

\footnotetext{
92 Del prólogo a sus Obras, I. Poesías, Madrid, Imprenta y Fundición de M. Tello, $3^{\text {a }}$ ed., 1881. Cito a través de Biblioteca Virtual Cervantes. El prólogo sería de 1857: Mariano Roca de Togores, Obras poéticas, pról. D. Juan Eugenio Hartzenbusch, Madrid, Tejado, 1857, 2 vols.

${ }_{93}$ Leopoldo Alas, La Regenta, ilustración de Juan Llimona, grabados de Gómez Polo, Barcelona, Daniel Cortezo y C. ${ }^{\text {a }}$, 1884-1885, 2 vols. Clarín entregaba el original del primer tomo hacia el otoño de 1884, el cual estuvo impreso a fines de año, distribuyéndose ya a comienzos de 1885. Vid. J. M. ${ }^{\mathrm{a}}$ Martínez Cachero, «Recepción de "La Regenta" in vita de Leopoldo Alas», en «Clarín» y «La Regenta» en su tiempo..., op. cit., pp. 71-92.

94 25-II-1883. M. Revuelta Sañudo (ed.), M. Menéndez Pelayo, Epistolario, VI, enero 1883noviembre 1884, Madrid, Fundación Universitaria Española, 1983, p. 34.
} 
signo. Se respetaron, pero nunca congeniaron. Si Fernández Grilo, poeta de éxito popular en la época, fue visto por los dos como la cabal encarnación de la vacuidad sonora, la estima de Alas por su paisano Campoamor fue siempre alta (aunque también le criticara), frente a la opinión contraria de Valera. Este no la recató en sus cartas, como tampoco en público, pero en el segundo caso solo para el que quisiera o supiera leer entre líneas ${ }^{95}$. En las que escribe a Menéndez Pelayo parece estar pensando esencialmente en un crítico: Clarín, aunque es probable que también aluda, en segundo término, a Valbuena. Denota lo primero el rebajamiento intencionado de Campoamor al nivel de Grilo, más la mención inicial de Cheste y Cánovas, figuras señeras en el infierno creado por el ovetense. Por otro lado, el ataque previo a Sellés disipa cualquier duda, sobre todo si volvemos la vista hacia una carta, de veinte días antes, al mismo destinatario:

...he visto las ponderaciones que hace Clarín (en el Progreso) del último drama de Sellés, y en seguida he leído los detestables y ridículos versos (tres o cuatro escenas) que pone luego para muestra. Si aquello es lo mejor, ¿cómo será lo restante? En fin, es menester resignarse a no escribir, o a no aspirar a más que a ocupar un puesto secundario, en pos de Sellés, de Echegaray o de otros por el estilo ${ }^{96}$.

Todo radicaba en la espera ante las opiniones de la crítica, creadora de fama y opinión. El libro poético de Menéndez Pelayo, con la carta-prólogo de su amigo y «mentor», justificaba sobradamente una respuesta en la prensa, y esta se hacía esperar. El malhumor de quien se hallaba lejos y disentía de lo que leía necesitaba, claro es, ser matizado a través de los días, pues los pasajes epistolares que cito obedecen al hic et nunc más perentorios, no habiendo sido escritos para los lectores de un futuro lejano (e indiscreto). Nosotros, sin embargo, no podemos dejar de advertir razones y calculadas estrategias: «Clarín, a pesar de sus manías, es de lo que más vale. Poco a poco importa traerle del lado nuestro, y quitarle un poquito de su mucho entusiasmo por Echegaray y Pérez Galdós, sin que lo pierda todo, pues ni nosotros mismos queremos ir contra la corriente y negar que Echegaray y Pérez Galdós valgan»97.

La opinión sobre Galdós cambiaría (escasamente la dedicada al matemático, ministro y fecundo dramaturgo José Echegaray), pero lo que aquí resalta es el deseo de armonizar en lo posible las opiniones de un crítico poderoso con las de una facción de los académicos, aquella que Clarín podía sentir más próxima. Valera sería consciente de que obraba con ventaja, pues la

\footnotetext{
${ }^{95}$ No tengo en cuenta las polémicas tardías, esgrima con careta y guantes blancos.

${ }^{96}$ Lisboa, 5-II-1883. Ibídem, pp. 20-21.

${ }^{97}$ Lisboa, 5-III-1883. Ibíd., p. 45.
} 
fidelidad del ovetense a su amigo y condiscípulo Menéndez Pelayo no tuvo nunca fisuras, pese a los disentimientos ideológicos. Ha de decirse a su favor que Valera jugaba, hasta cierto punto, con las cartas sobre la mesa; o engañaba con la verdad. En el mismo prólogo a los versos del amigo aseguraba que a este —el jovencísimo Menéndez Pelayo (ya autor por entonces de la Historia de los heterodoxos españoles y del Horacio en España)_le alababan hasta los «enemigos»:

Entre los encomiadores descuella un crítico duro, cruel, injusto a veces y sobrado descontentadizo; pero (estoy seguro de que no me engaña la gratitud) de agudísimo ingenio, de erudición varia y sana y de singular chiste y discreción en cuanto escribe, cuando la pasión de secta no le ciega: el señor D. Leopoldo Alas ${ }^{98}$.

Prueba de la sinceridad de estas palabras es su casi estricta correspondencia con otro elogio privado, tres años después de la carta-prólogo de la que he citado. En la dirigida desde Bruselas a Menéndez Pelayo, sentenciaba Valera:

Muchísimo celebraré que Clarín hable con detenimiento de mis versos. Miro yo a Clarín como el más discreto, inteligente y ameno de nuestros críticos de hoy que se ocupan de hablar de los autores contemporáneos, sin desconocer que es apasionado hasta la injusticia, exagerando, por ejemplo, ya los elogios a Campoamor, ya los dicterios para Velarde; pero, en fin, como Clarín nos trata bien a usted y a mí, le perdonamos sus excentricidades, porque nuestro recto juicio tiene por auxiliares la gratitud y el egoísmo ${ }^{99}$.

Ahora bien, Clarín, como mostraba el caso de Valbuena, creaba un modelo temible de crítica, con encumbramientos de los que se podía disentir y con unas víctimas a las que pocos querían socorrer. Recordable es la frase de Campoamor, sin duda agradecida: «El señor don Leopoldo Alas, que desde la ciudad de Oviedo pone en la actualidad más ideas en circulación que en su tiempo el padre Feijoo...»100. Observado en su conjunto, el trabajo fue titánico y

\footnotetext{
98 Op. cit., p. LXX de la introducción.

99 Bruselas, 16-VI-1886, en M. Menéndez Pelayo, Epistolario, VII, ed. cit., 1983, p. 573; y Melchor Fernández Almagro, «Crítica y sátira en Clarín», en J. Ma M. Cachero (ed.), Leopoldo Alas «Clarín», op. cit., pp. 147-153.

100 En J. Valera, OC, II..., p. 1641. La afirmación procede del volumen conjunto de Ramón de Campoamor y Juan Valera, La Metafísica y la Poesía. Polémica, Madrid, Sáenz de Jubera, Hnos., 1891. La afirmación no es de Valera, como erróneamente indica Adolfo Sotelo Vázquez en su, por otro lado, valioso artículo «Valera desde la óptica crítica de Clarín», en «Clarín» y «La Regenta» en su tiempo..., op. cit., pp. 921-937; 924.
} 
deslumbrante, pero cabe sospechar que algunos de los escritores coetáneos debían temblar si Clarín se interesaba por ellos.

Volviendo a Cheste, hubo de pasar el tiempo, morirse incluso el crítico, para que Valera quisiera defender al conde de los que le acusaban de danticida. Pero incluso entonces, cuando el viejo Valera ya estaba por encima del mal y del bien, su espíritu burlón no pudo dejar de advertir el voluntarioso esfuerzo del militar y académico ante traducciones y creaciones propias:

Tal vez, como el hijo de Filipo, Pezuela pierde la paciencia cuando tarda en desatar el nudo, y lo desbarata de una cuchillada, o bien, cuando la musa castellana se le resiste a expresar lo que desea, como al otro se le resistió la Pitonisa, la agarra de un brazo y la obliga por fuerza a pronunciar el oráculo ${ }^{101}$.

Cheste o Pezuela se hombreaba[n] con Alejandro Magno, pero para desatar los nudos de una rima. Atendido el contexto, el elogio global del esbozo biográfico y crítico tenía el veneno — suave, pero veneno- de quien no puede menos que señalar lo que ve y describirlo envuelto en gratos elogios de salón. Clarín, que pertenecía a una generación más joven y exigente, no había podido ni querido transigir. No dejaría de pagar por ello.

Con poca simpatía por su labor, el citado Moscatel le había propinado dos redondillas, una de ellas con fácil voluntad profética:

\footnotetext{
Cuando no quiere apuntar detalles, generaliza; mas si entrevé una paliza se complace en detallar.

Con sus ribetes y puntas de sabio, es algo pedante, y hay quien le augura el instante de pagarlas todas juntas ${ }^{102}$.
}

En estas mediocres «coplas» el profetismo no dejaba de ser raro, pues, además de atender al futuro (como es de ley), tenía también (a sabiendas o no) carácter retrospectivo. Clarín ya las había pagado todas juntas cuando ganó la cátedra de Economía Política y Estadística en la Universidad de Salamanca y fue desplazado del primer puesto (y desposeído, por tanto, de la cátedra) por el ministro de Fomento, Francisco de Borja Queipo de Llano y Gayoso, conde de

\footnotetext{
101 Juan Valera, Florilegio... Cito por OC, II..., p. 1296b.

102 Calabazas y cabezas..., op. cit., p. 153.
} 
Toreno, lo que sucedió en 1878. Al margen de influjos no propalables, ni acaso directos (el opositor preferido era hijo político del ama de leche de Alfonso XII), el manejo caprichoso de las ternas era el procedimiento para quitarse de encima a catedráticos demócratas e independientes, más o menos afectos al krausismo. El ministro elegía entre los tres primeros y podía deshacer, de este modo, prelaciones justas debidas tan sólo a los méritos intelectuales ${ }^{103}$. Otros parecían los tiempos a la altura de 1884-85, cuando un ministerio liberal había devuelto la cátedra a Clarín (ya en 1881), y al situarnos en los años de escritura y publicación de La Regenta, novela que ha deslumbrar, entre otros, a Galdós. Léase, sin embargo, lo que el ovetense confesaba a Menéndez Pelayo en este mismo periodo:

Si no ve algún artículo mío hace tiempo elogiando sus trabajos literarios, no lo achaque a pereza; es que me han echado, con buenos modos, de todos los periódicos de alguna circulación donde escribía.

Mis queridos correligionarios son así a veces (como los de usted); no comprenden que se alabe a los contrarios y se pegue, como ellos dicen, a los amigos.

A Dios gracias, todas estas pequeñeces no importan gran cosa ${ }^{104}$.

En términos más amplios, piénsese en la venganza de la crítica, detectable incluso en el agradecido Valera, en cuya voluminosa obra de crítica literaria Leopoldo Alas no sale más que accidentalmente, con menciones al paso y de no excesiva trascendencia ${ }^{105}$. Si el académico proyectó en su día un pacto o suma de fuerzas, si no dejó de admirar a Clarín (sobre todo cuando se sintió halagado por sus inteligentes críticas), pronto debió darse cuenta de que los posibles pactos no tenían futuro con aquel crítico «descontentadizo» e independiente, marcado por criterios estéticos muy ajenos a los suyos. Optó entonces por un ostensible silencio público, aunque en privado diera cuenta de opiniones favorables ${ }^{106}$. Quizás pensó que era mejor no arriesgar, a la vista de todos, una postura de excesivo acercamiento. Salvador María Granés retrataba de este modo al precavido don Juan:

103 Vid. la cáustica y magistral carta pública de Clarín «Al Sr. Francisco Queipo de Llano, a quien llaman el Conde de Toreno», La Unión, 109, 28-XII-1878, y en Ivan Lissorgues, Clarín político, II, Toulouse, Université de Toulouse-Le Mirail, 1981, pp. 97-99 y 54-60 del estudio.

104 M. Menéndez y Pelayo, Leopoldo Alas (Clarín), Epistolario, pról. G. Marañón, ed. Adolfo Alas, Madrid, Escorial, 1943, carta de diciembre de 1884, pp. 32-33.

105 Dicho sea al margen de la gratitud (epistolar) ante el ensayo sobre «Valera» en Nueva campaña, op. cit., pp. 89-98, lo que marcaría un cambio de actitud a partir de 1886, como analiza con pertinencia A. Sotelo Vázquez, art. cit., pp. 923 y ss.

106 Para completar el cuadro general, léase a José María Martínez Cachero, «Noticia de tres folletos contra Clarín», en J. Ma M. Cachero (ed.), Leopoldo Alas «Clarín», pp. 69-81. 


\author{
Escritor fino y correcto, \\ buen periodista y buen crítico, \\ no tiene más que un defecto, \\ que es el ser hombre político ${ }^{107}$.
}

\title{
V
}

Clarín, pues, decide escribir su poema de «Consulta crítica» en el lemosín de Cheste, dispuesto a escribir —él sí de verdad- en culto. Lo «siríaco», que escribió el de Molins, le llevó en su poema a lo egipcíaco o «menésico», avalado por Heródoto y los papiros de los egiptólogos, mientras que el latín y el griego, que tenía en la uña (como podía demostrar incluso en las páginas festivas de Madrid Cómico ${ }^{108}$ ), le sirvieron de feliz cantera para su despliegue de cultismos e invención de neologismos. De este modo, el raro poema quedaba abierto en sus detalles para pocos, como soberbio alarde de dominio lingüístico y técnico.

Hoy incluso podemos atisbar un juego interno que en junio de 1884, cuando «Consulta crítica» se edita por primera vez, nadie pudo entrever: la relación entre la «blonda fámula» o «fámula auricroma» del poema y Petra, la doncella de Ana Ozores en La Regenta, novela de la que Clarín todavía no había entregado a la imprenta ni una sola página, aunque ya hubiera empezado su redacción, al parecer en el otoño del año anterior ${ }^{109}$. Presentada en todo momento como «rubia azafranada», el novelista trazaría de su personaje este retrato: «Tenía la doncella algo más de veinticinco años; era rubia de color de azafrán, muy blanca, de facciones correctas; su hermosura podía excitar deseos, pero difícilmente producir simpatías»; por su lado más negro, Petra sería también «la rubia lúbrica [que] olfateaba la deshonra de aquel hogar»110.

El mundo entre cuatro paredes que rodea al enfermo presenta otras similitudes entre poema y novela. Los deberes de la doncella y los de otras criadas de la casa forman parte de las preocupaciones domésticas que el marido de la Regenta quisiera evitar a toda costa. Por su mente pasa la sarta de inconvenientes que se le vienen encima al caer enferma su mujer:

La botica, los jaropes que él aborrecía, el miedo a equivocar las dosis, el pavor que le inspiraban las medicinas verdosas, creyendo que podían ser veneno (para don Víctor el veneno, a pesar de sus estudios físico-químicos,

\footnotetext{
107 Op. cit., p. 135.

$108 \mathrm{O}$ en narraciones como «Vario», Cuentos, ed. Ángeles Lezama, estudio preliminar de Gonzalo Sobejano, Barcelona, Crítica, 1997, pp. 288-290.

109 La habría terminado a fines de abril de 1985. J. A. Cabezas, op. cit., pp. 132-136. Y Gonzalo Sobejano (ed.), intr. a L. A., La Regenta, Madrid, Castalia, 1981, I, p. 14.

110 Ed. J. Oleza, I, pp. 230, 232, 418, 471, etc.
} 
siempre era verde o amarillo), las equivocaciones y torpezas de las criadas, las horas de hastío y silencio al pie del lecho de la enferma... ${ }^{111}$

Es claro que el crítico del poema también yace enfermo, sometido a los descuidos de una criada que, en su irónica condición de «arúspice doméstico», controla todo el ámbito, externo e interno, de la habitación en penumbra. No solo anuncia la llegada del indeseado visitante, sino que rige la limpieza y provoca, por su culpable olvido, el accidente que ha de convertirse en un feliz «naufragio». Pero es lo cierto que accidente y enfermedad entran en terrenos de resbaladiza o indeseada verbalización - para el primor de la buena educación-, cuyos detalles el poeta vela irónicamente tras un lenguaje hiperculto. La situación se pliega a una actitud y sensibilidad que ha de manifestar a su modo el marido de la Regenta cuando esta yazga enferma:

Todos los días había que palpar el vientre y hacer preguntas relativas a las funciones más humildes de la vida animal; don Víctor, que no se fiaba de su memoria, siempre reloj en mano, llevaba en un cuaderno un registro en que asentaba con pulcras abreviaturas, y con estilo gongorino, lo que al médico importaba saber de estos pormenores ${ }^{112}$.

El omitido «estilo gongorino» ya había triunfado en el poema de «Consulta crítica». Era como si el novelista hubiera ensayado antes la descripción de la vida de un enfermo y los posibles incidentes novelescos que pueden rodearla, bien es cierto que en el poema bajo un punto de vista paródico, lejos de la crisis física y anímica que ha de sufrir Ana Ozores. El yo del poema se confunde con la imagen pública que de sí proyectaba Clarín; la Regenta, diríamos, es un desdoblamiento novelesco, sujeto a sus propias leyes, del yo del autor. El primero puede permitirse todas las ironías; el segundo, solo de modo reflejo, por medio de un espectador o espectadores, sea cualquiera de los otros personajes o el yo del narrador, que salpicará los hechos con sus observaciones o subrayados. Son dos planos diferentes: el de la intimidad de la sufriente Ana Ozores; el de la peculiar consulta que sufre el crítico. En uno y otro Clarín nos muestra, por vía distinta, su maestría ${ }^{113}$.

Bajando al detalle, cabe una primera y doble observación sobre el estilo impostado del poema: la constante elección de palabras esdrújulas y el uso de raros términos jurídicos, propios de un conocedor de la Historia del Derecho, materia de la que el sabio autor era catedrático en la Universidad de Oviedo. El despliegue se muestra, por ejemplo, en la caracterización del «visitante», que

111 Ed. J. Oleza, II, p. 175. El subrayado es mío.

112 Ibídem, II, p. 179 y n.

113 Sobre metaliteratura y parodia en La Regenta, vid. J. Oleza, ed. cit., intr., pp. 69-71. 
recibe, además de este, los siguientes nombres: «proxena», «Tespis», «hóspite», «vate». Desde el abismo de la realidad el hablante en plebeyo se confiesa a sí mismo como antiguo «sereno», «capataz» y «destajista». Es el triunfo del «rústico sermo»y de la misma realidad desdeñada por el soñador, que aspira a ser hóspite de las musas y enriquecerse con ello, a pesar de su insalvable rudeza. El parodiado «lemosín» del traductor de Dante se convertía en una lengua ambigua - mezcla de altos cultismos y bajas palabras cotidianas-, con un grado de acumulación irónica que conecta con el estilo achulado de ciertos personajes del género chico y del futuro Valle-Inclán de los esperpentos. El DRAE de 1884 decía para «hirsuto», uno de los términos del poema: «Úsase en lenguaje poético y científico». Si a la fusión en un todo unitario de las dos vertientes connotativas añadimos un quid de rara ironía, tendríamos algo semejante a lo que es el estilo de este poeta satírico, que no puede negar una vieja raíz universitaria. Y es que al cientifismo del XIX (o a la actitud que ese cientifismo conlleva) se unen saberes de una cierta antigüedad. En el «argento», «fámula», «mancipio», «ósculo», «oscular», «Apolo Esminteo», «manucapi» o «apropincuarse» suena una vieja veta de estudiantes de latín y humanidades grecolatinas que ya se oye, con su correspondiente carga de ironía anticulterana, en el teatro del XVII; así, en boca de un gracioso tirsiano:

Hacia mi dueño enfermizo se apropincua una buscona, y yo a los dos me apropincuo ${ }^{114}$.

Recuérdense igualmente las burlas de la fregatriz que se finge condesa en El lindo don Diego, de Moreto, y que enamora con palabras abstrusas al bobo caballero, el cual se rinde ante lo que no entiende:

\begin{tabular}{|c|c|}
\hline BEATRIZ & $\begin{array}{l}\text { ¿Qué intento os lleva, neutral } \\
\text { a mis coturnos, cortés? }\end{array}$ \\
\hline DON DIEGO & $\begin{array}{l}\text { (¡Jesús, cuál habla! Esto es } \\
\text { estilo de sangre real.) [...] }\end{array}$ \\
\hline BEATRIZ & $\begin{array}{l}\text { Remito, por lo que expreso, } \\
\text { la locución otro día. }\end{array}$ \\
\hline DON & ¿En efeto seréis mía? \\
\hline EAT & Cogitación habrá en eso ${ }^{115}$. \\
\hline
\end{tabular}

\footnotetext{
114 Bellaco sois, Gómez, II, vv. 1655-1667, del gracioso Montilla. De una comedia atribuida, con sólido fundamento, a Tirso, escrita hacia $1640 . \mathrm{M}^{\mathrm{a}}$. Dolores Montero Reguera, Edición, anotación y estudio de «Bellaco sois, Gómez», comedia atribuida a Tirso de Molina, Madrid, UAM, 2004, p. 268 (tesis doctoral).

115 Ed. cit., II, vv. 1657-1660 y 1745-1748.
} 
En la recreación tardía de ese estilo cómico cabría hablar de una lengua de «escolares» que hoy casi se ha extinguido (al menos en esa veta), pero que para Clarín, o para su admirado condiscípulo Menéndez Pelayo, estaba aún completamente viva. Es una lengua petulante y cultista que Valle-Inclán ha de adoptar, con estilo y habilidad propios, en su obra satírica de madurez.

Es, también, desde su origen, una lengua de ecos, los cuales se traslucen en un modo de énfasis oral que es constante en el estilo de Clarín. Nace esta vertiente de la repetición burlesca de frases o construcciones hechas, tópicos que el escritor subraya literalmente, con la correspondiente cursiva. Valga este ejemplo de La Regenta:

Al considerar esta mala suerte de las compañías dramáticas en Vetusta, podría creerse que el vecindario no amaba la escena, y así es en general; pero no faltan clases enteras, la de mancebos de tienda, la de los cajistas, por ejemplo, que cultivan en teatros caseros el difícil arte de Talía, y con grandes resultados, según El Lábaro y otros periódicos locales ${ }^{116}$.

«El difícil arte de Talía» es una construcción afín a la de «el carro de Tespis», que aparece en el poema, si bien allí rota y transformada de modo radical: «...aquel Tespis / digno del carro...». En un periódico que no era El Lábaro de Vetusta, pero que sin duda podría haber competido con él, un cronista de 1885 elogiaba «el hermoso collar de obras dramáticas que D. José Echegaray ha ceñido al ebúrneo cuello de la Talía Española»117.

Los ecos de expresiones y frases pueden serlo también de citas, difusas o concretas. De nuevo en la novela, Quintanar, el marido de la Regenta, palmea las ancas del hermoso caballo de don Álvaro Mesía:

- Hola, hola,

hipógrifo violento,

que corriste parejas con el viento

—dijo don Víctor, que manifestaba a menudo su buen humor recitando versos del Príncipe de nuestros ingenios o de algún otro de los astros de primera magnitud118.

No es preciso llegarse hasta el mundo modernista de Luces de bohemia, tan lleno de citas y recuerdos literarios de todo tipo ${ }^{119}$. Esa lengua de «escolares»

116 Ed. J. Oleza, II, p. 85. Las ediciones modernas regularizan el uso de la cursiva en la mención de «el Lábaro», así citado, sin énfasis alguno (ya lo encierra el nombre) en la primera edición (II, p. 29).

117 Tous de Monsalve, «Crónica», Revista Malacitana, I, 7 (15-III-1885).

118 Ibídem, II, p. 78. Sangro, no obstante, los dos versos, y no solo el segundo, como en la primera edición (II, p. 25), lo que crea un raro desajuste. 
a que he aludido recrea voces, frases y saberes de modo similar a como sucede en el mundo de los escritores y poetas, empapados de modelos memorizados que en un momento son ensalzados y al siguiente derribados de su alta columna. Son dos vetas coincidentes, las dos presentes en Clarín, bien sea mediante las aficiones literarias o latiguillos culturales de un personaje, que es así caracterizado, o bien por medio de la ironización absoluta de una lengua culta y técnica, propia de un profesor universitario (en la ficción poética, y por vía interpuesta, la de un presidente de la Real Academia Española).

Lo curioso es que, desde ese plano, y aunque no fuera de ningún modo la intención del autor, los impecables endecasílabos blancos de Madrid Cómico se convertían en el revés paródico del «verso libre» ensayado por Menéndez Pelayo en su libro de Odas, epístolas y tragedias. Puede ejemplificarse con un fragmento de la «Carta a mis amigos de Santander, con motivo de haberme regalado la Bibliotheca Graeca de Fermín Didot»:

¡Venid a mí, despedazados torsos
de estatuas inmortales: rotos himnos
de Alceo, de Stesícoro y Simónides,
donde aún alienta el genio en cada sílaba!
¡Dísticos vengadores de Tirteo,
que del duro lacón el pecho inflaman
en la feroz mesénica contienda!
Y templen tal horror con dulce halago
el himno de Baquílides suavísimo,
o la voz grave del anciano ascreo,
o el canto pastoril siracusano,
o un enjambre de abejas, desprendidas
de la hiblea, antológica colmena'

El clasicismo macarrónico (intencionadamente macarrónico... a ratos) del poeta ovetense suponía una reverencia, sincera y profunda, a los poetas y pasajes ensalzados por el poeta santanderino ${ }^{121}$, pero desde su sometimiento al contraste con el rústico sermo de la realidad. Idealización y caricatura se

\footnotetext{
119 Como analizó A. Zamora Vicente en un estudio clásico: La realidad esperpéntica. Aproximación a «Luces de bohemia», Madrid, Gredos, 1974.

120 Epístola a mis amigos de Santander, Madrid, Imprenta Central, 1879, pp. 9-10; y en Poesías, II. Odas, epístolas y tragedias, Madrid, CSIC, 1955, pp. 60-71; 64. Reduzco mayúsculas.

121 Ya elogiados en textos como «A Menéndez Pelayo, con motivo de la publicación de sus poesías. Epístola jocoseria, en estilo familiar y verso libre e independiente», La Ilustración Española y Americana, XXVII, 10 (15-3-1883), p. 163; ...Sermón perdido (crítica y sátira), Madrid, Ricardo Fe, 1885, pp. 259-263. Quede para otro lugar la consideración de este primer ensayo (en Clarín) de verso libre, y de su relación con el contexto de época.
} 
sometían a un último filtro: la lengua impostada y falsa del de Cheste. El resultado era claro: el ovetense escribía en una lengua difícil e inventada - dura, además, de descifrar-: el lemosín cultilatino.

Cabe examinarlo en una última derivación, que mostraría la supuesta huella gongorina. Tras sus versos, Clarín remataba: «Paréceme que no se puede narrar más en culto un suceso prosaico, pero providencial e histórico». Narrar en culto nos lleva inevitablemente a don Luis de Góngora y, sin embargo, poco o casi nada de gongorino (directo) hay en el poema, salvo en un verso, en el que el estilo de don Luis suena desvaído a través de la mecánica repetición de sus hallazgos en la mala poesía del mismo XIX, con un «ondas de cristal» en lugar de 'agua bullente' o 'en movimiento'. En la lengua poética del cordobés «cristal» puede manifestar un doble valor metafórico: 'agua', si «sonora», y 'miembros de cuerpo femenino', si «muda»122. A partir de entonces para muchos poetas no habría agua que se preciara que no fuera, antes que nada, «cristal», el cual puede tener, como sublime adorno, ondas de esmeralda o de zafiro. Esclarece ese estilo pluscuampoético una preciosa cita del novelista colombiano Jorge Isaacs:

En el lujoso valle do serpean

corrientes de zafir, al sol que la enamora detiene y embelesa, cristiana Sunamita, la hermosa Medellín.

Jazmines y floridos naranjales sus perfumes le da, y arroyos de los montes descienden a brindarle, en baños de odalisca, sus ondas de cristal ${ }^{123}$.

Las consabidas ondas, en boca de Isaacs o de Zorrilla, eran despojos del Gran Bazar de joyas de la poesía, y no digamos el rutilante «zafir» y los «baños de odalisca», que, aun pasados por Ingres o Delacroix, tienen el encanto, casi perfecto, de la más pura ingenuidad poética. El ovetense sabía de sobra estas cosas, como demuestra en sus críticas y paliques, con lo cual miraba hacia el entorno sin descuidar otros ecos (incluido el latinizante «argento» entre ellos).

«En ondas de cristal bebió naufragios» redime, por imitación ridícula, un tópico verbal y rescata, para acentuar la burla, otros ecos barrocos, sean de Góngora o de Quevedo, poeta que intensificó las construcciones metafóricas con

122 En el Polifemo Acis «su boca dio, y sus ojos cuanto pudo, / al sonoro cristal, al cristal mudo». Dámaso Alonso, Góngora y el «Polifemo», Madrid, Gredos, 1994, pp. 507, 510.

123 «La tierra de Córdoba, VIII», Poesías completas, intr. B. Sanín Cano, Barcelona, Maucci, s. a., pp. 106-107. 
«beber». En el soneto amoroso «Si mis párpados, Lisi, labios fueran» hiperbolizaba, en efecto, Francisco de Quevedo:

Tus bellezas, hidrópicos, bebieran

$\mathrm{y}$, cristales sedientos de cristales, de luces y de incendios celestiales alimentando su morir, vivieran ${ }^{124}$.

«Cristal» da, bien se sabe, para corrientes aguas, puras, cristalinas, como ya en Garcilaso, pero también para miembros o cuerpos de transparente o luciente cristal, como en Góngora, o para ojos que brillan con incendios que conceden muerte y dan vida al anegarse, sedientos, en bullentes cristales de hermosura. Toda esa tradición, ya gastada en mano de imitadores de imitadores de imitadores, podía ir a parar, con el drama escrito en hirsuto papel barba, a un prosaico orinal. Allí sucumbían los sueños de otro autor de lo que sin duda habría sido una versión puesta al día de El gran cerco de Viena, la pomposa y vana obra del escritor satirizado por Leandro Fernández de Moratín en La comedia nueva o El Café.

124 Obra poética, I, ed. J. M. Blecua, Madrid, Castalia, 1969, p. 644. Modifico la puntuación. Véase la anotación de Pablo Jauralde (ed.), en Antología poética, Madrid, Espasa Calpe, 2002, pp. 177-180. 